\title{
Aquifer configuration and geostructural links control the groundwater quality in thin-bedded carbonate-siliciclastic alternations of the Hainich CZE, central Germany
}

\author{
Bernd Kohlhepp $^{1}$, Robert Lehmann ${ }^{1}$, Paul Seeber ${ }^{1}$, Kirsten Küsel ${ }^{2,3}$, Susan E. Trumbore ${ }^{4}$, and Kai U. Totsche ${ }^{1}$ \\ ${ }^{1}$ Friedrich Schiller University Jena, Institute of Geosciences, Chair of Hydrogeology, \\ Burgweg 11, 07749 Jena, Germany \\ ${ }^{2}$ Friedrich Schiller University Jena, Institute of Ecology, Chair of Aquatic Geomicrobiology, \\ Dornburger Strasse 159, 07743 Jena, Germany \\ ${ }^{3}$ German Centre for Integrative Biodiversity Research (iDiv), Halle-Jena-Leipzig, \\ Deutscher Platz 5d, 04103 Leipzig, Germany \\ ${ }^{4}$ Max Planck Institute for Biogeochemistry Jena, Department of Biogeochemical Processes, \\ Hans-Knöll-Str. 10, 07745 Jena, Germany \\ Correspondence to: Kai U. Totsche (kai.totsche@uni-jena.de)
}

Received: 21 July 2016 - Discussion started: 5 September 2016

Revised: 4 October 2017 - Accepted: 17 October 2017 - Published: 1 December 2017

\begin{abstract}
The quality of near-surface groundwater reservoirs is controlled, but also threatened, by manifold surfacesubsurface interactions. Vulnerability studies typically evaluate the variable interplay of surface factors (land management, infiltration patterns) and subsurface factors (hydrostratigraphy, flow properties) in a thorough way, but disregard the resulting groundwater quality. Conversely, hydrogeochemical case studies that address the chemical evolution of groundwater often lack a comprehensive analysis of the structural buildup. In this study, we aim to reconstruct the actual spatial groundwater quality pattern from a synoptic analysis of the hydrostratigraphy, lithostratigraphy, pedology and land use in the Hainich Critical Zone Exploratory (Hainich CZE). This CZE represents a widely distributed yet scarcely described setting of thin-bedded mixed carbonatesiliciclastic strata in hillslope terrains. At the eastern Hainich low-mountain hillslope, bedrock is mainly formed by alternated marine sedimentary rocks of the Upper Muschelkalk (Middle Triassic) that partly host productive groundwater resources. Spatial patterns of the groundwater quality of a $5.4 \mathrm{~km}$ long well transect are derived by principal component analysis and hierarchical cluster analysis. Aquifer stratigraphy and geostructural links were deduced from lithological drill core analysis, mineralogical analysis, geophysical borehole logs and mapping data. Maps of preferential
\end{abstract}

recharge zones and recharge potential were deduced from digital (soil) mapping, soil survey data and field measurements of soil hydraulic conductivities $\left(K_{\mathrm{S}}\right)$. By attributing spatially variable surface and subsurface conditions, we were able to reconstruct groundwater quality clusters that reflect the type of land management in their preferential recharge areas, aquifer hydraulic conditions and cross-formational exchange via caprock sinkholes or ascending flow. Generally, the aquifer configuration (spatial arrangement of strata, valley incision/outcrops) and related geostructural links (enhanced recharge areas, karst phenomena) control the role of surface factors (input quality and locations) vs. subsurface factors (water-rock interaction, cross-formational flow) for groundwater quality in the multi-layered aquifer system. Our investigation reveals general properties of alternating sequences in hillslope terrains that are prone to forming multilayered aquifer systems. This synoptic analysis is fundamental and indispensable for a mechanistic understanding of ecological functioning, sustainable resource management and protection. 


\section{Introduction}

Near-surface groundwater reservoirs are increasingly threatened by anthropogenic impact, like the intensification of agricultural land use and water production, while their ecological functioning is still rather unexplored. Generally, the hydrogeochemical and (micro)biological compositions of shallow $(<200 \mathrm{~m})$ groundwater systems are a result of biogeochemical processes and the fluid-rock/soil interactions while travelling through the overburden of the aquifers (Urich, 2002; Canora et al., 2008). Infiltrating precipitation, as the main component of recharge of the surface near groundwater systems, first passes the soils. Thereby, the seepage collects among others dissolved organic carbon (Guggenberger and Kaiser, 2003), colloidal, mineral, organic and organo-mineral suspended particles (Münch et al., 2002; Totsche et al., 2006, 2007; Schrumpf et al., 2013; Gleixner, 2013) and even biota (Dibbern et al., 2014). The residence time of the percolating water in the soils as well as in the unsaturated and saturated zones regulates the chemical and biological quality by the extent to which the partial equilibrium of the rate-limited dissolution, retardation and release processes is achieved (Weigand and Totsche, 1998; Münch et al., 2002). Residence times and thus groundwater quality depend on various surface factors (duration and intensity of precipitation, land management/vegetation, presence of macropores) and subsurface factors (i.e. soil thickness, hydraulic parameters and preferential flow paths).

However, subsurface factors are spatially very variable in fractured rock and carbonate-rock terrains (Cook, 2003), and their relative importance for recharge and groundwater quality is still poorly understood (Gleeson et al., 2009). Sustainable management and resource protection therefore call for a holistic investigation of surface-subsurface architecture and interactions for the reconstruction of the hydrogeological functioning and groundwater quality. Concepts for vulnerability assessment (Hölting et al., 1995; Goldscheider et al., 2000; Witkowski et al., 2003; Vías et al., 2006), for instance, already consider the variable interplay of surfacesubsurface factors and compartments in a thorough way, but disregard the evolution of pristine groundwater quality. Conversely, hydrogeochemical case studies (i.e. Suk and Lee, 1999; Moore et al., 2009) often lack a comprehensive analysis of the structural buildup and composition of the entire compartments, whereas the important "biogeoreactor" of the overburden soils is vastly neglected. Studies that include land use and soil groups (Pronk et al., 2009; Steward et al., 2011; Allocca et al., 2014) typically leave groundwater chemistry out of their focus. In this study, we follow a holistic approach for reconstructing the pristine groundwater quality in the aquifers of the Hainich Critical Zone Exploratory (Hainich CZE) in central Germany. Here, the bedrock of fractured, mixed carbonate-siliciclastic alternations represents a widely distributed yet scarcely described geological setting. We synoptically characterize all surface and subsurface com- partments involved in the flow of water and transport of matter in the subsurface of the Hainich CZE. The goals of our study are (1) to understand the hydrogeological and biogeochemical functioning of the subsurface in a setting provided by the Hainich CZE that so far has not been adequately addressed, (2) to explore the links and feedbacks between the surface and subsurface, and (3) to demonstrate that a holistic multi-method approach that considers the surface and subsurface factors is indispensable for the mechanistic understanding of the coupling of surface and subsurface compartments, fluid dynamics, biogeochemical element cycling and ecology in the critical zone.

To reach these goals, the following research questions are answered. (i) How is the critical zone comprised and connected in the hillslope setting of a thin-bedded, mixed carbonate-siliciclastic succession? (ii) How do spatial arrangement, particularly outcrop patterns and geostructural links (karst features like caprock sinkhole lineaments), impact compartment connection (intrinsic vulnerability) and groundwater quality? Does groundwater quality in contrasting summit/midslope and footslope wells reflect surface influences? And finally: (iii) what are the main control parameters for groundwater quality? What are the reasons for particular hydrogeochemical conditions within the multistorey/hillslope aquifer system?

\section{Site description}

The Hainich Critical Zone Exploratory covers $430 \mathrm{~km}^{2}$ of a hillslope subcatchment of the Unstrut River in north-western Thuringia, central Germany (Fig. 1). It is bounded by the recipient Unstrut River and the distribution area of the Upper Muschelkalk formations. The Hainich represents a NW-SE orientated geological anticline that is developed topographically as a low-mountain range with a steep western flank and a moderately inclined eastern flank (Jordan and Weder, 1995). The study area is located at the eastern flank of the Hainich hillslope that shows a geostructural buildup with NE dipping strata in the direction of the syncline of MühlhausenBad Langensalza (Kaiser, 1905; König, 1930; Patzelt, 1998; Wätzel, 2007). Tectonic uplift, faulting and tilting of strata are assumed for the Late Cretaceous in analogy to the surrounding horst structures Thüringer Wald (in the south) and Harz (in the north; compare to Voigt et al., 2004; Kley and Voigt, 2008). The outcropping strata in the study area comprise sedimentary rocks (Middle/Upper Muschelkalk and Lower Keuper - subgroups of the Middle Triassic). According to the German stratigraphy (Deutsche Stratigraphische Kommission, 2002), the Diemel formation (Middle Muschelkalk), Trochitenkalk, Meissner, and Warburg formation (Upper Muschelkalk) and the Erfurt formation (Lower Keuper) outcrop in the study area. The Upper Muschelkalk subgroup, which hosts the target aquifers of the Hainich CZE, is organized by bio- and litho-stratigraphic marker beds (Ockert 

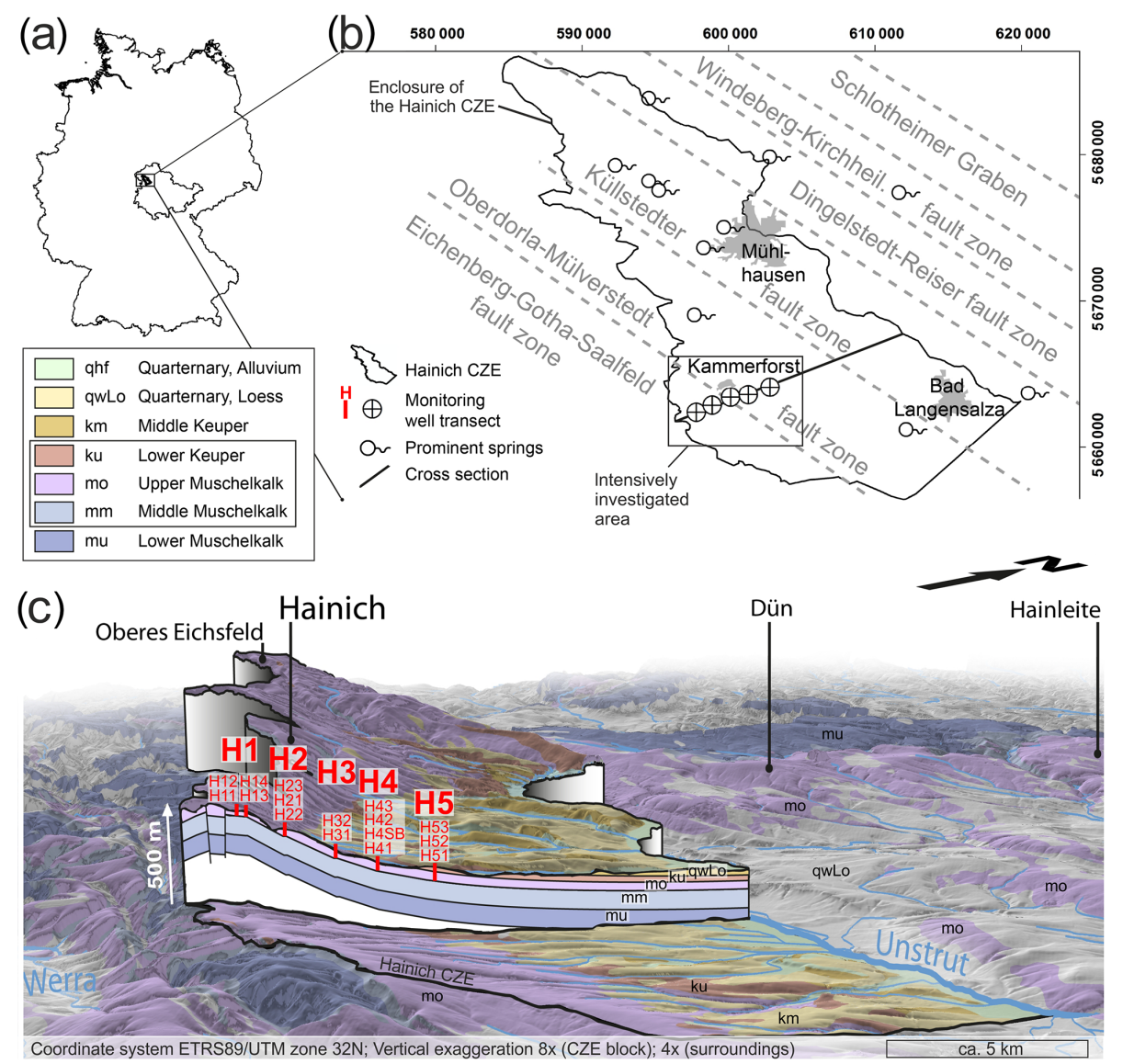

Figure 1. Location of the Hainich CZE $(\mathbf{a}, \mathbf{b})$ : prominent karst springs in the Hainich CZE are coupled to NE-SW orientated fault zones (b; modified from Mempel, 1939, and Jordan and Weder, 1995). (c): geological setting of the eastern Hainich hillslope with monitoring wells of the research transect, accessing Upper Muschelkalk target formations (mo). Data sources: DEM $\odot$ GeoBasisDE/TLVermGeo, gen. no.: $7 / 2016$.

and Rein, 2000; Kostic and Aigner, 2004). Previous studies hydrostratigraphically organize the Upper Muschelkalk subgroups into a Hainich Transect Lower Aquifer Assemblage (HTL) and a Hainich Transect Upper Aquifer Assemblage (HTU; Küsel et al., 2016). The area belongs to the $\mathrm{Cfb}$ climate region $(\mathrm{C}$ : warm temperate, f: fully humid, b: warm summer) according to the Köppen-Geiger classification (Kottek et al., 2006) and exhibits a leeward decline in areal precipitation and increasing mean air temperature from the Hainich ridge $\left(>900 \mathrm{~mm}_{\text {year }}{ }^{-1} ; 7.5-8^{\circ} \mathrm{C}\right)$ to the Unstrut Valley $\left(<600 \mathrm{~mm}\right.$ year $^{-1}$; $9-9.5^{\circ} \mathrm{C}$; long-term average 1970-2010, TLUG, 2016). The intensively investigated study area is limited to a $29 \mathrm{~km}^{2}$ subarea of the Hainich CZE, which surrounds the soil and groundwater monitoring transect (Küsel et al., 2016).

The Hainich CZE is a multifarious environmental laboratory for multiscale geo- and bio-science research, as

1. both the geological setting so scarcely described (alternations of marine thin-bedded limestones and marl- stones) and the hillslope relief/sloping aquifer configuration are common and widely distributed;

2. the monitoring plot and well transect (see Küsel et al., 2016) provide unique access to the multi-layered aquifer system of the common setting;

3. it represents a rare anthropogenically low-impacted (non-contaminated) cultural region in central Europe with a very extensive type of land management during the last centuries, allowing the investigation of natural (surface) signal transformation in the pristine aquifer systems and of ecosystem functioning;

4. the geostructural and lithological properties were found to be predictable, and thus enable the tracking of biogeochemical cycling and quality development within single aquifer storeys; and

5. the Hainich is a regionally important groundwater recharge area in Thuringia (Fig. 1) and an example of peripheral groundwater supply for water-deficient sed- 
imentary basins (Rau and Unger, 1997; Hiekel et al., 2004).

\section{Material and methods}

For the detailed and synoptic analysis of the critical zone and the aimed reconstruction of the groundwater quality control factors, we apply a multi-method approach that comprises drill core and geophysical-log analysis, geological surveys, soil and groundwater samplings, soil hydraulic measurements and a statistical analysis of groundwater hydrogeochemistry.

\subsection{Groundwater well transect}

The Upper Muschelkalk strata are accessed by a hillslope transect that consists of multiple wells at five sites for groundwater monitoring, termed H1 to H5. Each site contains one to four drilled wells. Sites H1 (wells H11 to 14) and $\mathrm{H} 2$ (H21 to H23) are located in the summit/shoulder region of the catchment, which is covered by forest. Sites H3 (H31/32), H4 (H41 to H43 and additional sweep well H4SB) and H5 (H51 to H53) are situated in the agriculturally used, midslope and footslope regions of the Hainich low-mountain range.

\subsection{Hydrogeochemistry and hydraulics}

Groundwater levels were recorded by permanently installed data loggers (Orpheus Mini, Ecolog 500/800, OTT Hydromet $\mathrm{GmbH}$, Germany). Groundwater was sampled at least every 4 weeks over 3 hydrological years (November 2013 to October 2015) in 15 permanent monitoring wells (5.1 to $88.5 \mathrm{~m}$ final depth below the surface) of five sites along the $5.4 \mathrm{~km}$ long well transect (Fig. 1) between 417 and $244 \mathrm{~m}$ a.s.l. (metres above mean sea level). The groundwater wells were sampled with submersible motor pumps (MP1, Grundfos, Denmark) or, in the case of very low water levels, with bladder pumps/bailers. The physicochemical parameters of groundwater samples were measured on-site using a flowthrough cell equipped with probes for temperature $(T), \mathrm{pH}$ (SenTix 980, WTW GmbH, Germany), electrical conductivity, temperature corrected to $25^{\circ} \mathrm{C}$ (EC_25) (TetraCon 925), redox potential (Eh) (SenTix ORP 900), and dissolved oxygen $\left(\mathrm{O}_{2}\right)$ (FDO 925). Hydrochemical analyses (duplicates) comprised major and minor ions $(<0.45 \mu \mathrm{m}$, PES filter) by ICP-OES (725 ES, Varian/Agilent, USA) and ICPMS (Thermo Fisher Scientific, Germany; Thermo Electron, UK), acid and base neutralizing capacity by acid-base titration, major anions $\left(\mathrm{SO}_{4}^{2-}, \mathrm{Cl}^{-}, \mathrm{NO}_{3}^{-}, \mathrm{NO}_{2}^{-}, \mathrm{PO}_{4}^{3-}\right.$; PES filter $<0.45 \mu \mathrm{m}$ ) by ion chromatography (DX-120, DIONEX, USA), redox-sensitive parameters $\left(\mathrm{Fe}^{2+}, \mathrm{NO}_{2}^{-}, \mathrm{NH}_{4}^{+}, \mathrm{HS}^{-}\right.$) by colorimetry (DR/890, Hach, USA) and determination of carbon sum parameters (TOC, TIC, DIC, DOC; PES filter $<0.45 \mu \mathrm{m}$ ) by high temperature catalytic oxidation (multi 18
N/C 2100S, AnalytikJena, Germany). Groundwater was classified using a Piper plot (Piper, 1944) following Furtak and Langguth (1967) and Kralik et al. (2005).

\subsection{Statistical analysis}

SPSS 22 (IBM Corp., USA) and Origin Pro 2015 (OriginLab Corp., USA) were used for descriptive and multivariate statistics of the hydrochemical data. This includes hierarchical cluster analysis (HC) for distinguishing hydrogeochemical groups independently from lithostratigraphy-based hydrostratigraphy. Two different parameter sets were statistically examined at the same number of groundwater analysis from three hydrological years. A complete parameter set (a), including all measured parameters, was chosen to identify the parameters that control the hydrochemical compositions of the groundwater domains by means of principal component analysis (PCA). As redox processes seem to be very distinct in the studied groundwaters (masking other processes), a limited parameter set (b) was defined that does not include ions which are strongly affected by redox processes. The complete parameter set (a) contains EC_25, pH, $\mathrm{O}_{2}$, Eh, TOC, anions $\left(\mathrm{NO}_{3}^{-}, \mathrm{Cl}^{-}, \mathrm{SO}_{4}^{2-}\right)$, cations $\left(\mathrm{Ca}^{2+}, \mathrm{Mg}^{2+}\right.$, $\mathrm{Mn}^{2}$ and ${ }^{4+}, \mathrm{K}^{+}, \mathrm{Na}^{+}, \mathrm{Fe}^{2}$ and $\left.3+, \mathrm{Zn}^{2+}, \mathrm{Sr}^{2+}, \mathrm{Ba}^{2+}\right)$ and silica $\left(\mathrm{Si}^{4+}\right)$. The limited parameter set (b) includes EC_25, $\mathrm{pH}, \mathrm{Cl}^{-}, \mathrm{Ca}^{2+}, \mathrm{Mg}^{2+}, \mathrm{K}^{+}, \mathrm{Na}^{+}, \mathrm{Zn}^{2+}, \mathrm{Sr}^{2+}, \mathrm{Ba}^{2+}$ and $\mathrm{Si}^{4+}$. Data preparation for $\mathrm{HC}$ includes a $z$-score normalization of concentrations. Strongly correlating variables $(>0.9)$ and constant values were excluded, outliers were eliminated (next neighbour method) and list-wise deletion was carried out (following Backhaus et al., 2016). Then, a Euclidian distance measure was applied and five clusters were chosen based on visual inspection of the scree plot elbow criterion (Cattell, 1966). The phenon line was chosen at a linkage distance of about 67. Thus, samples with a linkage distance lower than 67 were grouped into the same cluster. Finally, Ward's method for clustering was applied (Ward, 1963).

\subsection{Field survey}

A total of 482 bedrock outcrops were investigated for lithology, flow paths, karst features and the thickness of Quaternary cover sediment. Strike and dip directions were constructed based on the mapped boundary between two prominent formations (Trochitenkalk/Meissner formation). Soil profiles were described for 117 ramcore drillings (GSH 27, Robert Bosch GmbH, Germany; $50 \mathrm{~mm}$ and $60 \mathrm{~mm}$ diameters, drilled to the bedrock; up to $5 \mathrm{~m}$ depths) and 154 supplementary soundings (Pürckhauer, $22 \mathrm{~mm}$ ). Soil description was carried out according to the German soil survey instruction (Bodenkundliche Kartieranleitung KA5, AG Boden, 2005) and the world reference base (WRB) scheme (IUSS Working Group WRB, 2006). Soil colours were determined using a Munsell soil colour chart. 
Soil hydraulic conductivities $\left(K_{\mathrm{s}}\right)$ were measured at two depths $(10$ and $30 \mathrm{~cm})$ at 16 locations (duplicates) within the potential groundwater catchment area by using a Guelph Permeameter (2800K1, Soilmoisture, USA). Soil hydraulic conductivities were calculated according to the equations in Elrick and Reynolds (1992, p. 320ff.). Hydraulic conductivities for each site are calculated as the harmonic average of the topsoil and subsoil (or parent rock in Ah/C soils). Mean values of hydraulic conductivities of soil groups are given as spatially weighted arithmetical means.

\subsection{Analysis of drill cores and borehole logs}

For the determination of the stratigraphic succession, aquifer properties and mineralogical indicators for groundwater flow, $395 \mathrm{~m}$ of drill cores from 12 drillings were investigated. Lithology, fractures/pores and rock weathering were described according to DIN EN ISO 14689-1. We extended this geotechnical rock classification to sedimentary structures, limestone classification (Dunham, 1962), pore classification (Lucia, 1983), degrees of karstification, aquifer types, fracture angles and fracture colours, as well as secondary mineralization on fractures. Additional information about stratigraphy, clay content, fracturing and groundwater inflow was revealed by analysing geophysical open-borehole logs of 10 drillings (sites H1/2/3/4/5, Fig. 1). This included data on calipers, passive gamma-ray radiation, sonic velocity (delay time of sound waves), specific electrical resistivity of rocks, as well as the temperature and specific electrical resistivity of the well water. Gamma-ray curves are interpreted based on the graphical interpretation of high gamma-ray peaks (marlstones) and intersections of gamma-ray curves with an empirically defined "shale line", here at 90 API (separating limestones from marlstones).

Rock-forming minerals were analysed by X-ray diffraction (Bruker D8 Advance, $\mathrm{Cu}-\mathrm{K} \alpha, 40 \mathrm{kV}, 40 \mathrm{~mA}$, Bruker AXS Inc., USA) and Fourier transform infrared spectroscopy (FTIR; Nicolet iS10; Thermo Fisher Scientific; USA).

\subsection{Grain size analysis of soils}

Grain size analysis of all major soil groups (144 duplicates) was carried out on filtered $(<125 \mu \mathrm{m})$, decarbonized $(\mathrm{HCl})$ and organic-free $\left(\mathrm{H}_{2} \mathrm{O}_{2}\right)$ samples (Laser Particle Sizer, Analysette 22, Fritsch, Germany).

\subsection{Geospatial analysis and construction of preferential groundwater recharge areas}

Maps of soil groups and geology were created and jointly analysed with aerial imagery and a digital elevation model (DEM, 2 m resolution) using ArcGIS 10.3 (ESRI Inc., USA). The primary data sets were interpreted in terms of land use types, surface morphology and drainage patterns, with a special focus on karst phenomena like caprock sinkholes, which are considered preferential input structures for funnelled in- filtration (Nennstiel, 1933; Mempel, 1939; Hecht, 2003). The two-dimensional correlation of geophysical and geological well $\log$ s was carried out with the GeoDIN V.8 well management software (Fugro Consult GmbH, Germany) by graphical correlation of prominent high gamma-ray peaks and stratigraphic marker beds (grainstones/rudstones). The spatial correlation of marlstones presumes that basin-centre marlstones are laterally more continuous than shallow water limestones (Aigner, 1985). In accordance with published examples for multi-storey subsurface architecture (Haag and Kaupenjohann, 2001; Heinz and Aigner, 2003; Klimchouk, 2005; Sharp, 2007), we use the term "aquifer storey" to emphasize our conceptualization of the fine-stratified setting by arbitrary definition of intervals that are dominated by fractured limestone beds and confined at the top and base by unfractured or low permeable beds, the latter with an effective minimum thickness of $80 \mathrm{~cm}$. The degree of aggregation is a compromise between increased detail to account for different hydrogeochemical patterns and the necessary well yield for recovering water samples.

\subsection{Soil group map}

The soil group map was constructed from different geospatial data sources, including (1) a land management map (interpreted from satellite images and field observations), (2) outcrop areas of surface geology (mapping data) and (3) DEM2. After conversion into raster data, a (4) slope gradient map and a (5) topographical position index (TPI; Weiss, 2001) map with an empirically chosen radius parameter of $75 \mathrm{~m}$ were calculated using the "Slope" function of the ArcMap toolbox. The slope position/relief position (i.e. shoulder, midslope) was calculated using the "Relief Analysis" tool of ArcGIS (Deumlich et al., 2010). It considers slope gradient, relative elevation and profile curvature (concave/convex) by using the slope gradient (4) and the TPI raster (5). The spatial distribution of soil groups was calculated with a query function, which considers land management, slope position and slope gradient for the following substrata: "carbonate soil series", "mixed carbonate-siliceous soil series", "claystone series" and "loess loam series".

\subsection{Groundwater recharge potential map}

For the determination of preferential zones for infiltration/recharge, we calculated qualitative maps of the recharge potential (compare to Muir and Johnson, 1979; Shaban et al., 2006; Deepa et al., 2016) in ArcGIS 10.3 by a weighted linear combination of surface-subsurface properties that influence water infiltration and percolation. The input raster data sets and the respective weight factors were chosen based on expert knowledge and the best fit to measured soil hydraulic conductivities: aquifer storey overburden thickness (40\%), type of bedrock (limestone-dominated vs. marlstonedominated strata; $15 \%$ ), soil classes $(15 \%)$, fracture/karst 
zones $(10 \%)$, vegetation and type of land management $(10 \%)$, soil thickness (5\%) and slope angle classes (5\%).

\section{Results}

\subsection{Surface characteristics of the Hainich CZE}

\subsubsection{Relief and surface water network in the groundwater catchment}

The study area ranges from the Hainich ridge (topographic water divide) towards the Unstrut Valley and covers altitude regions between 170 and $494 \mathrm{~m}$ a.s.l. with an average slope of $35 \mathrm{~m} \mathrm{~km}^{-1}$. Two orders of relief types are distinguished here: the first order (regional) relief grades from the culmination of the Hainich low-mountain range towards the lowangle midslope $\left(<5^{\circ}\right)$ and footslope. The second order (local) relief is formed by a bundle of 10 straight, parallel and roughly equidistant, SW-NE orientated transverse valleys with slopes $>5^{\circ}$. Second order relief elements are also the two NW-SE orientated lineaments of more than 80 caprock sinkholes (which are passive karst phenomena) with up to $80 \mathrm{~m}$ in diameter. Caprock sinkholes are mostly exhibited on local ridges. A second and parallel lineament of three shallow elongated (uvala-like) karst depressions with a horizontal extent of up to $400 \mathrm{~m}$ crosses the lower Hainich hillslope (Fig. 2a). A few small contact springs occur in the study area. Larger springs occur at the lower eastern slopes of the Hainich ridge, tracing regional fault/fracture zones. Headwater areas of creeks, small rivers, transverse valleys and even agricultural drainage ditches are mostly dry. During our monitoring period (November 2013 to May 2016) stream runoff typically occurred from December to March.

\subsubsection{Land management and history of land management}

Major types of land management are agriculture (crop, pasture) and forest (unmanaged and managed deciduous forest). Forests are to a large extent within the unmanaged Hainich National Park that occupies summit to midslope positions. Extensive forest management has been the dominant type of land management during all time periods, even with no deforestation during the Middle Ages (Otto, 2000). Mode of forest operation shifted from random selection of wood via coppice use (since the 15th century) and planter forestry (since the 20th century) to unmanaged woodland with the foundation of the Hainich National Park in December 1997 (Otto, 2000; Röhling and Safar, 2004). Parts of the study area $(12 \%)$, which are actually unmanaged grassland/scrubland areas within the Hainich National Park, had been previously used as a military training area since 1964, particularly for tank training from 1980 until 1990 (Otto, 2000; Poser, 2004). Cultivated grasslands outside the Hainich National Park, which are used both as meadows and pastures, cover parts of the midslope and locally some cleared glades at the shoulder as well as riparian areas of small rivers. Cropland (locally used for wheat, corn and canola production) covers mainly the midslopes and footslopes (Fig. 2a). Agricultural plots are typically large due to organization by the GDR's agricultural production cooperatives (from 1945 to 1990). These plots are now (since 1990) managed by privately owned agricultural cooperatives.

\subsection{Soils in the groundwater catchment}

\subsubsection{Soil distribution and soil development}

Soils cover the entire landscape with major soil series developed from carbonate rocks ("carbonate soil series": Rendzic Leptosols to Chromic Cambisols), siliciclastic rocks ("siliceous soil series": Luvisols, Stagnosols) or alluvial sediments (WRB and German soil groups: Table 1). Culmination areas and adjacent shoulder positions are covered with Cambisols. Small plateaus and spurs between transverse valleys in shoulder positions exhibit Chromic Cambisols which grade into Cambic Regosols on the shoulder and Calcaric Regosols on the midslope. Chromic Cambisols are also found in local depressions and old caprock sinkholes. Rendzic Leptosols occur in form of narrow patches in western crestal areas (close to well H11). Luvisols are coupled to the spatial distribution of loess loam in the central and eastern midslope/footslope areas. In case of a very thin loess loam cover, soils are developed as Pelosol-Cambisol and Cambisol. Fluvial soils cover the central parts of headwater areas and the complete valley floor in the lower parts (in the north-east) of the study area. Colluvisols occur at the margins of local valley flanks in the shoulder and midslope area (Fig. 2b). Typical sequences of two superimposed soils comprise (i) Chromic Cambisols (paleosols) developed from marlstones and (ii) Luvisols developed from loess loam with windblown loess sedimentation after the formation of soil (i) (Fier, 2012). Average soil thicknesses are $21 \mathrm{~cm}$ (for Rendzic Leptosols), $32 \mathrm{~cm}$ (Rendzic LeptosolCambisol transitions), $66 \mathrm{~cm}$ (Cambisols), $54 \mathrm{~cm}$ (Chromic Cambisols), $71 \mathrm{~cm}$ (Luvisols), $132 \mathrm{~cm}$ (Fluvisols), $91 \mathrm{~cm}$ (Stagnosols) and $78 \mathrm{~cm}$ (Colluvisols). Subsoils show higher average clay and fine silt content compared to the topsoils of the same soil group (Fig. 3).

\subsubsection{Soil hydraulic properties}

Average (median) soil hydraulic conductivities $\left(K_{\mathrm{S}}\right)$ of the five major soil groups infer that Cambisols and Luvisols (1.3 to $1.5 \times 10^{-4} \mathrm{~m} \mathrm{~s}^{-1}$ ) form the most conductive soil cover in the study area, followed by Rendzic Leptsols and Chromic Cambisols (2.5 to $5 \times 10^{-5} \mathrm{~m} \mathrm{~s}^{-1}$ ) and Stagnosols (about $6 \times 10^{-7} \mathrm{~m} \mathrm{~s}^{-1}$; Table 1, Figs. 3 and 8). Topsoils of Chromic Cambisols are considerably more conductive than those in Rendzic Leptosols and Luvisols. Generally subsoils are less 
Table 1. Soil groups (WRB, 2003, and AG Boden, 2005), soil texture and soil hydraulic properties.

\begin{tabular}{|c|c|c|c|c|c|c|}
\hline WRB soil group & $\begin{array}{l}\text { Rendzic Lep- } \\
\text { tosols, Calcaric } \\
\text { Regosols }\end{array}$ & $\begin{array}{l}\text { Chromic Cam- } \\
\text { bisols }\end{array}$ & Cambisols & Luvisols & Stagnosols & Fluvic Cambisol \\
\hline $\begin{array}{l}\text { German soil } \\
\text { group }\end{array}$ & $\begin{array}{l}\text { Rendzina, } \\
\text { Pararendzina }\end{array}$ & Terra fusca & Braunerde & Parabraunerde & Pseudogley & Vega \\
\hline Substratum & $\begin{array}{l}\text { limestone, } \\
\text { marlstone }\end{array}$ & limestone & $\begin{array}{l}\text { marlstone, } \\
\text { loess loam }\end{array}$ & $\begin{array}{l}\text { loess loam, } \\
\text { marlstone }\end{array}$ & $\begin{array}{l}\text { loess loam, } \\
\text { marlstone }\end{array}$ & alluvial silt + clay \\
\hline Thickness & $5-35 \mathrm{~cm}$ & $85-100 \mathrm{~cm}$ & $35-80 \mathrm{~cm}$ & $50-100 \mathrm{~cm}$ & $80-190 \mathrm{~cm}$ & up to $330 \mathrm{~cm}$ \\
\hline Soil category & $\begin{array}{l}\text { medium silty } \\
\text { clay }\end{array}$ & $\begin{array}{l}\text { slightly silty } \\
\text { clay }\end{array}$ & $\begin{array}{l}\text { medium silty } \\
\text { clay }\end{array}$ & $\begin{array}{l}\text { slightly clayey } \\
\text { silt }\end{array}$ & $\begin{array}{l}\text { medium silty } \\
\text { clay }\end{array}$ & $\begin{array}{l}\text { strongly silty } \\
\text { clay }\end{array}$ \\
\hline Median grain size $(\mu \mathrm{m})$ & $12.6 \pm 3.6$ & $13.3 \pm 4.9$ & $13.2 \pm 3.6$ & $17.3 \pm 4.2$ & not & $17.8 \pm 5.0$ \\
\hline$\%$ clay + fine silt & $34.0 \pm 7.8$ & $33.9 \pm 9.7$ & $32.3 \pm 7.0$ & $27.0 \pm 9.4$ & measured & $25.6 \pm 9.1$ \\
\hline $\begin{array}{l}\text { Water storage } \\
\text { capacity }\end{array}$ & low & high & high & medium & very high & very high \\
\hline Roots & $<35 \mathrm{~cm}$ & $30-60 \mathrm{~cm}$ & $20-80 \mathrm{~cm}$ & $20-180 \mathrm{~cm}$ & $30-80 \mathrm{~cm}$ & $15-40 \mathrm{~cm}$ \\
\hline $\begin{array}{l}\text { Cracks and } \\
\text { borrows }\end{array}$ & $\begin{array}{l}\text { earthworm bor- } \\
\text { rows down to } \\
\text { the host rock }\end{array}$ & $\begin{array}{l}\text { earthworm bor- } \\
\text { rows down to } \\
\text { the host rock }\end{array}$ & frequent & $\begin{array}{l}\text { deep borrows } \\
\text { (voles, worms) }\end{array}$ & $\begin{array}{l}\text { limited to shal- } \\
\text { low soil hori- } \\
\text { zons }\end{array}$ & $\begin{array}{l}\text { limited to shallow } \\
\text { soil horizons }\end{array}$ \\
\hline Decarbonatization & no & complete & $\begin{array}{l}\text { almost } \\
\text { complete }\end{array}$ & complete & incomplete & no \\
\hline \multirow[t]{2}{*}{$\begin{array}{l}\text { Typical colour } \\
\text { (subsoil) }\end{array}$} & yellowish grey & $\begin{array}{l}\text { dark yellowish } \\
\text { grey }\end{array}$ & brownish grey & yellowish grey & greenish grey & yellowish grey \\
\hline & $10 \mathrm{YR} 3 / 2$ & $7.5 \mathrm{YR} 4 / 3$ & $10 \mathrm{YR} 5 / 6$ & $10 \mathrm{YR} 4 / 6$ & $2.5 \mathrm{Y} 4 / 2$ & $10 \mathrm{YR} 4 / 3$ \\
\hline $\begin{array}{l}\text { Hydromorphic } \\
\text { attributes }\end{array}$ & no & oxidative & oxidative & oxidative & $\begin{array}{l}\text { oxidative }+ \\
\text { reductive } \\
\text { motteling }\end{array}$ & $\begin{array}{l}\text { oxidative }+ \\
\text { reductive } \\
\text { motteling }\end{array}$ \\
\hline Soil water & $>200 \mathrm{~cm}$ & $\begin{array}{l}\text { rarely and } \\
>80 \mathrm{~cm}\end{array}$ & $\begin{array}{l}\text { rarely and } \\
>100 \mathrm{~cm}\end{array}$ & $\begin{array}{l}\text { rarely and } \\
>100 \mathrm{~cm}\end{array}$ & $\begin{array}{l}\text { commonly in } \\
1-2 \mathrm{~m}\end{array}$ & $\begin{array}{l}\text { very commonly } \\
>40-60 \mathrm{~cm}\end{array}$ \\
\hline $\begin{array}{l}\text { Morphologic } \\
\text { position }\end{array}$ & $\begin{array}{l}\text { midslope }+ \text { all } \\
\text { steep local } \\
\text { slopes }\end{array}$ & $\begin{array}{l}\text { culmination }+ \\
\text { local plateaus }\end{array}$ & $\begin{array}{l}\text { culmination to } \\
\text { midslope }\end{array}$ & $\begin{array}{l}\text { footslope, (and } \\
\text { midslope) }\end{array}$ & $\begin{array}{l}\text { footslope, } \\
\text { valley }\end{array}$ & valley centre \\
\hline Land use & $\begin{array}{l}\text { forest }+ \text { mil- } \\
\text { itary training } \\
\text { area }\end{array}$ & $\begin{array}{l}\text { forest }+ \text { some } \\
\text { grassland }\end{array}$ & $\begin{array}{l}\text { cropland, } \\
\text { grassland, } \\
\text { forest }\end{array}$ & $\begin{array}{l}\text { cropland, } \\
\text { grassland, } \\
\text { uncommonly } \\
\text { forest }\end{array}$ & $\begin{array}{l}\text { grassland, } \\
\text { uncommonly } \\
\text { forrest }\end{array}$ & grassland \\
\hline Anthropogenic changes & $\begin{array}{l}\text { compacted } \\
\text { (tanks), drained }\end{array}$ & uncommon & $\begin{array}{l}\text { ploughed, com- } \\
\text { pacted }\end{array}$ & $\begin{array}{l}\text { ploughed, com- } \\
\text { pacted }\end{array}$ & drained & drained \\
\hline $\begin{array}{l}\text { Hydraulic } \\
\text { conductivity } K_{\mathrm{S}} \\
\left(\mathrm{m} \mathrm{s}^{-1}\right) \\
(\text { median, } \pm \mathrm{SD})\end{array}$ & $\begin{array}{l}5.2 \times 10^{-5} \\
\pm \\
4.9 \times 10^{-5}\end{array}$ & $\begin{array}{l}2.5 \times 10^{-5} \\
\pm \\
1.2 \times 10^{-5}\end{array}$ & $\begin{array}{l}1.5 \times 10^{-4} \\
\pm \\
5.2 \times 10^{-5}\end{array}$ & $\begin{array}{l}1.2 \times 10^{-4} \\
\pm \\
1.2 \times 10^{-4}\end{array}$ & $6.5 \times 10^{-7}$ & not measured \\
\hline
\end{tabular}



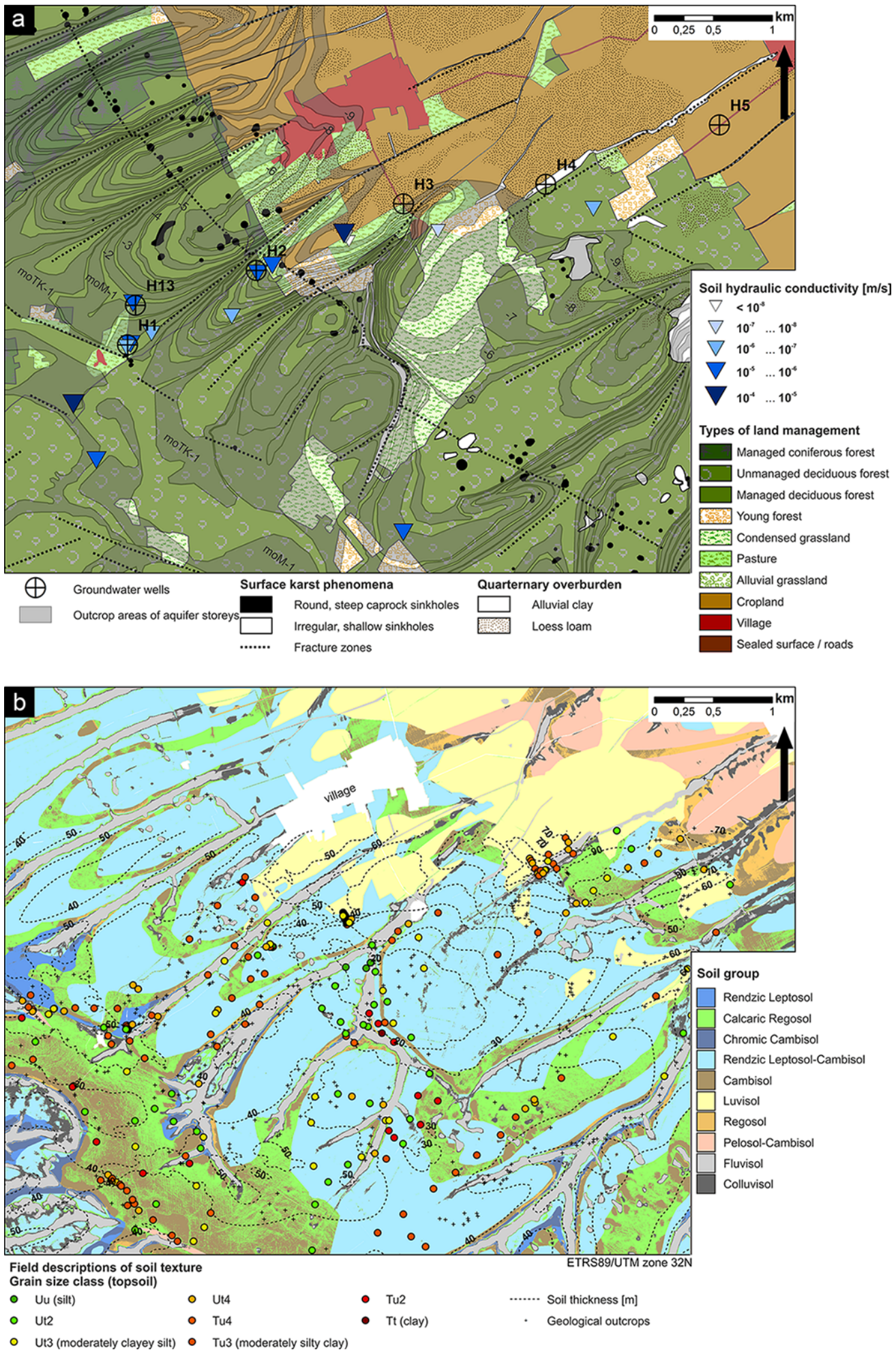

Figure 2. (a) Types of land management, outcrop zones of aquifer storeys, sinkhole lineaments, potential fracture zones, and measurement points for soil hydraulic conductivities. Aquifer storeys which are lower in stratigraphy outcrop in higher positions on the Hainich hillslope. The AquaDiva well transect H1 to H5 (also shown) covers hillslope regions from the summit (H1) to the footslope (H5). (b) Soil map showing calculated soil groups and mapped calibration data points. Signatures of the mapped soil profiles represent the grain size class (soil category) of the topsoil. Interpolated isolines of mapped soil thickness show increasing thickness towards the north-east and towards the transverse valleys. 


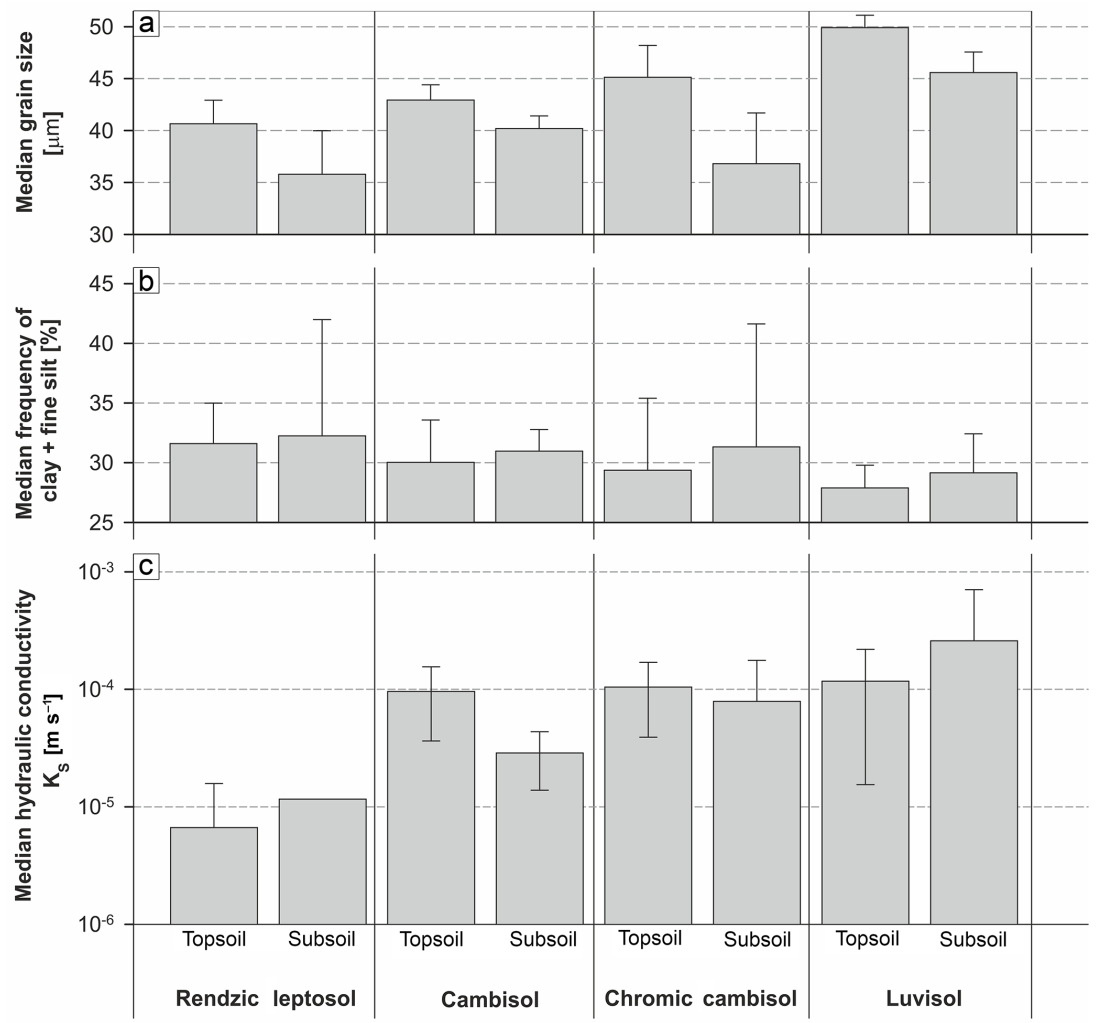

Figure 3. Physical properties of topsoils/subsoils and parent rocks of the four major soil groups. Median grain size decrease (a) and the frequencies of the fine grain size fractions (clay + fine silt) increase towards the subsoil (b), respectively. (c): median soil hydraulic conductivities of soil groups showing higher median soil hydraulic conductivity in Chromic Cambisols and Luvisols compared to the Rendzic Leptosols and Cambisols and general decreases in hydraulic conductivity towards the subsoil. The error bars describe the root of the estimation variance of the average.

conductive than topsoils of the same location. Soil hydraulic conductivities $\left(K_{\mathrm{s}}\right)$ are essentially uncorrelated with the soil texture (i.e. correlation $K_{\mathrm{S}}$ vs. median grain size: Spearman $\left.r^{2}=+0.17\right)$. Soil thickness is uncorrelated with the slope gradient $\left(r^{2}=-0.24\right.$ and barely better if slope positions are correlated individually).

\subsubsection{Geological outcrop zones}

The landscape of the Hainich low-mountain range has been developed within the Triassic formations of the Upper Muschelkalk and Lower Keuper. All formations outcrop in distinct zones along the eastern slope with dip angles steeper than the slope: from $5^{\circ}$ (footslope) to $8^{\circ}$ (shoulder position); and lower/older strata outcrop in higher relief positions (Fig. 2a). A NW-SE orientated normal fault is located close to the Hainich summit with offsets of about $10 \mathrm{~m}$ (Fig. 2a). Fault-bound troughs (up to $700 \mathrm{~m}$ long and $150 \mathrm{~m}$ wide) are also found parallel to this fault. The Triassic rocks are covered by young loess loam in sheltered, concave depressions of the east-exposed slopes. Alluvial soils and colluvia fill the valley bottoms with increasing thickness (maximum $3.5 \mathrm{~m}$ ) and areal cover from the midslope to the footslope (Fig. 2a).

\subsection{Subsurface properties of the Hainich CZE}

\subsubsection{Lithostratigraphy and bedrock mineralogy}

The stratigraphic succession is characterized by thin-bedded carbonate-siliciclastic alternations of which only the limestone beds are fractured and therefore represent potential aquifers. The Diemel formation ( $\mathrm{mmDO}$ ) comprises thin (1$3 \mathrm{~cm}$ ) yellowish dolomitic marlstones and fine crystalline dolomite, and rarely cavernous dolomites without any fossils, gypsum or salt. The $7 \mathrm{~m}$ thick Trochitenkalk formation $($ moTK) with thick $(5-30 \mathrm{~cm})$, grey, coarse bioclastic limestones (mainly rudstones with the rock-forming fossil Encrinus liliformis) forms a carbonate-rock-fracture aquifer with minor karstification (intrastratal karst according to Ford and Williams, 2007). Large-scale (metre-scale) and consistent fractures, a high fracture index and dissolution-enlarged fractures and vugs (Lucia, 1983), as well as karst breccia at the base of the formation are common features. The fractures found in rock cores are mainly developed as stratabound (Odling et al., 1999) fractures that are restricted to the limestone beds, as is common in limestone-marlstone alternations (Meier et al., 2015). All fractures and pores are 
stained with red brownish (10R6/6) coatings. Karst features in the Trochitenkalk formation occur from the near surface down to $90 \mathrm{~m}$ in depth. Rock mineralogy is dominated by calcite and very low contents of dolomite with trace amounts of quartz, muscovite, chlorite and Na-/K-feldspar. Based on a consistent (moTK) formation thickness, bed thickness and limestone types (cf. Dunham, 1962) in all wells, lateral facies changes within the Trochitenkalk formation are negligible.

The $34.6 \mathrm{~m}$ thick Meissner formation (moM) consists of $5 \mathrm{~m}$ thick basal marlstones with three discrete bioclastic limestone beds (Kalkbank $\alpha / \beta / \gamma$ ), overlain by $29 \mathrm{~m}$ of alternating thin $(2-5 \mathrm{~cm})$ limestones (mudstones to grainstones) and marlstones. These are covered by a thick $(>60 \mathrm{~cm})$ bioclastic, regional biostratigraphic marker horizon, the $\mathrm{Cy}-$ cloidesbank, which is a known regional aquifer (Grumbt et al., 1997; Hecht, 2003) of minor importance. Limestones in the Meissner formation are fracture aquifers and their rock matrices are predominantly composed of calcite and trace amounts of dolomite, quartz, illite and feldspar. The overlaying $16 \mathrm{~m}$ thick Warburg formation $(\mathrm{moW})$ with predominantly marlstones (mineralogically: calcite, dolomite, quartz) and the $35 \mathrm{~m}$ thick Erfurt formation (kuE) with dolomite rocks (dolomite, calcite and quartz), siltstones, silty sandstones and claystones (illite, muscovite, chlorite and gypsum) represent both unfractured aquitards (Hoppe, 1952; Hecht, 2003) and form the low permeable top-seal strata of the Upper Muschelkalk aquifer storeys at the footslope positions (Table 2). The Triassic strata are bounded by an erosional unconformity on top, which is overlain by aeolian loess loam developed from loess deposits of the last glacial period (Weichsel glacial in Germany; Greitzke and Fiedler, 1996) and alluvial/colluvial sediments of Holocene age (Rau and Unger, 1997).

\subsubsection{Hydrostratigraphy}

The correlation of sedimentological core logs and geophysical borehole logs infers that a multi-layer hydrostratigraphy is applicable and that all aquifers and aquitards are presumably continuous (and with a similar thickness and limestone type) on the scale of the research transect (Fig. 4). In the Upper Muschelkalk strata Trochitenkalk formation (moTK) and Meissner formation (moM), the alternated bedding of limestones, marlstones and claystones results in permeable fracture aquifers (dense matrix, varying fracturing) and low permeable marlstones (dense matrix, unfractured). Ten aquifer storeys are newly defined for the Hainich CZE. Of these, the Trochitenkalk formation contains one aquifer storey (moTK1) and the Meissner formation contains nine aquifer storeys (moM-1 to moM-9; Table 2). All footslope aquifer storeys are overlain by impermeable cap rocks of the Warburg formation (Upper Muschelkalk) and the Erfurt formation (Lower Keuper). Flow paths are predominantly fractures and matrix porosity is lower than $5 \%$ in all stratigraphic intervals. Although it is of a karst-fracture type with partially solution- enlarged fractures, the karstification and the development of conduits are limited and concentrated at the formations' very base. Below moTK-1, the impermeable dolomitic marlstones of the Diemel formation (mmDO) form a hydraulic basis seal. We observed an intact and unweathered base seal in all wells that were drilled to the base of moTK-1. The Meissner formation $(\mathrm{moM})$ contains limestone-fracture aquifers which are interbedded marlstone aquitards on the decimetre to metre scale. Limestones of this formation are almost exclusively fracture aquifers with very little matrix porosity, concentrated at certain thickly bedded limestone marker beds.

\subsubsection{Land use types and soils within the outcrop zones of aquifer storeys}

The outcrop zones of the two lowermost aquifer storeys (moTK-1, moM-1) are predominantly covered by forest, whereas the outcrop zones of stratigraphically higher storeys show mixed types of land management, including forest, cropland and pasture (Fig. 5a). Within the aquifer outcrop zones, the four major soil groups (Rendzic Leptosol, Leptic Cambisol, Cambisol and Chromic Cambisol) are present in different spatial proportions (Fig. 5b). Significant proportions of Luvisol cover the outcrop areas of moM-7, moM9 and moTK-1. Stagnosol and Colluvisol are restricted to the outcrop area of mm, moTK-1 and moM1-4. The grain size classes of subsoils show a slight trend of increasing silt content towards the outcrop zones of stratigraphically higher aquifer storeys (moTK-1 to moM-9). Argillaceous soils occur frequently in moM-4 to moM-6. Pure clay as a subsoil category is restricted to moM-2 and moM-7 (Fig. 5c).

\subsection{Groundwater chemistry}

\subsubsection{Groundwater classification}

The groundwater in the carbonate rock landscape is classified as weakly to strongly mineralized earthalkaline, bicarbonatic type (site H1/2/3/4), and earthalkaline, bicarbonaticsulfatic type (cf. TLUG, 1996) for groundwater of deep well $\mathrm{H} 51$ (moTK-1). The order of abundance for dissolved ions is $\mathrm{Ca}^{2+}>\mathrm{Mg}^{2+}>\mathrm{Na}^{+}>\mathrm{K}^{+}$and $\mathrm{HCO}_{3}^{-}>\mathrm{SO}_{4}^{2-}>\mathrm{Cl}^{-}$. According to the groundwater subtypes of Kralik et al. (2005), the moM waters (except for well H14) plot in the "dolomite" field, and moTK-1 waters (wells H13/21) and water from H14 (moM) plot in the "calcite" field. All other moTK1 wells (H31/41/51) are classified as the mixed subtype ("calcite+dolomite"). Two contact springs in the recharge area (Grauröder Quelle, Ihlefeldquelle) and two karst springs in the discharge area (Kainspring, Melchiorbrunnen, coupled to NW-SE orientated fault zones) are classified as carbonateearth alkaline type predominantly in contact with calcite in the recharge area and a calcite-dolomite mixing type in the discharge area. Groundwater chemistry in aquifer storeys in 
Table 2. Hydrostratigraphic standard section: relative positions of aquifer storeys (this study) in comparison with a published classification (Küsel et al., 2016) in the context of the German stratigraphy and the timescale.

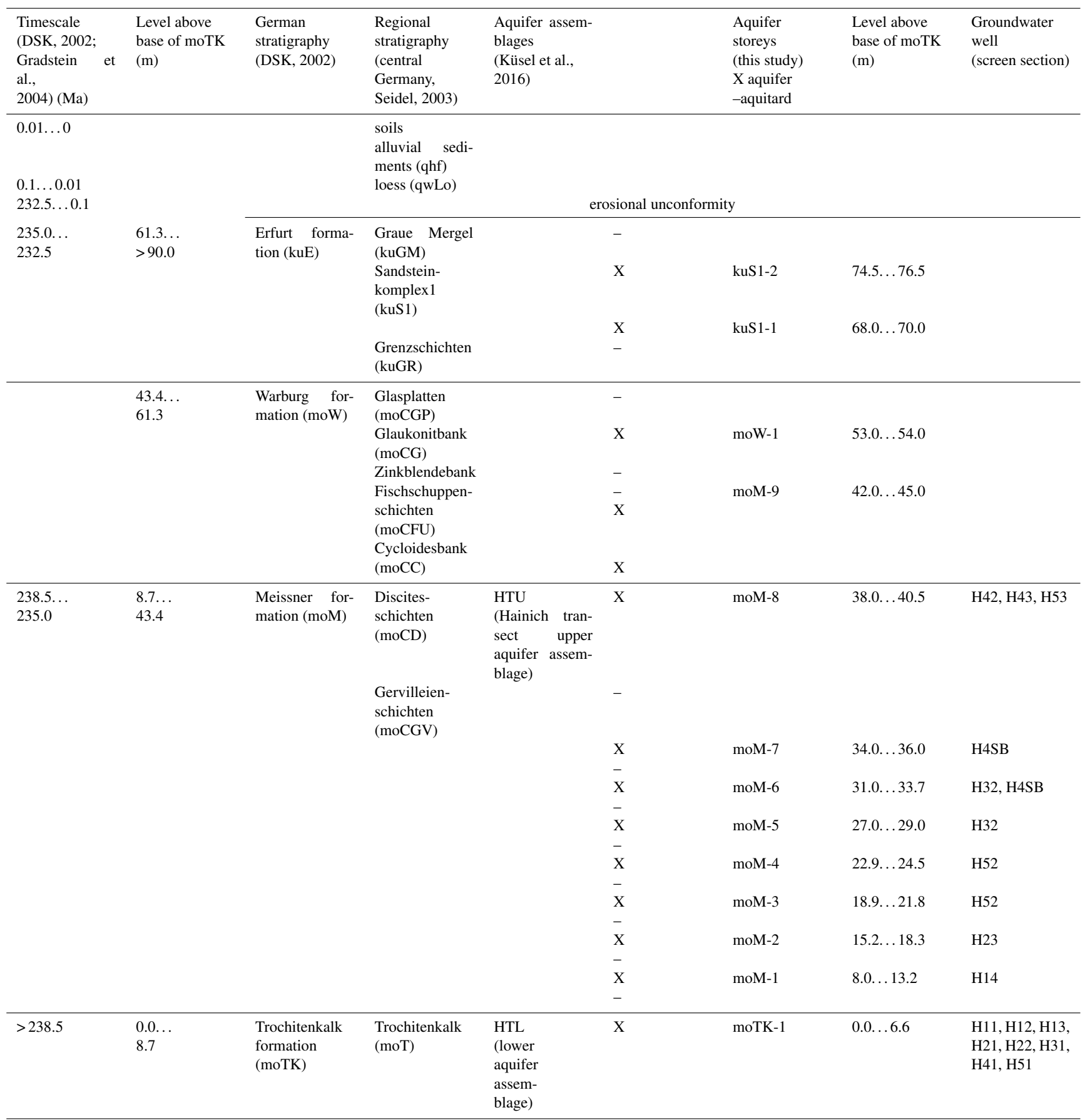

deeper stratigraphic positions exhibits high $\mathrm{O}_{2}, \mathrm{SO}_{4}^{2-}$, and $\mathrm{Sr}^{2+}$ and low $\mathrm{Mg}^{2+}, \mathrm{HCO}_{3}^{-}, \mathrm{Si}^{4+}, \mathrm{K}^{+}, \mathrm{Na}^{+}$, and $\mathrm{NO}_{3}^{-}$concentrations. Shallow aquifer storeys are partly anoxic in midslope/footslope positions and deeper aquifer storeys are oxic in all slope positions (Fig. 6). Aquifers in footslope wells show higher concentrations of $\mathrm{K}^{+}, \mathrm{Mg}^{2+}, \mathrm{Si}^{4+}, \mathrm{Sr}^{2+}, \mathrm{SO}_{4}^{2-}$ and $\mathrm{Cl}^{-}$compared to the same aquifer in summit positions.

\subsubsection{Statistics of hydrogeochemistry and chemical composition of groundwater groups}

Hierarchical cluster analysis revealed five clusters. Cluster 1 comprises the groundwater samples from upper slope moTK1 wells (H13/21) and moM-1 well H14. Cluster 2 encompasses the groundwater samples from moTK-1 wells H31/41 


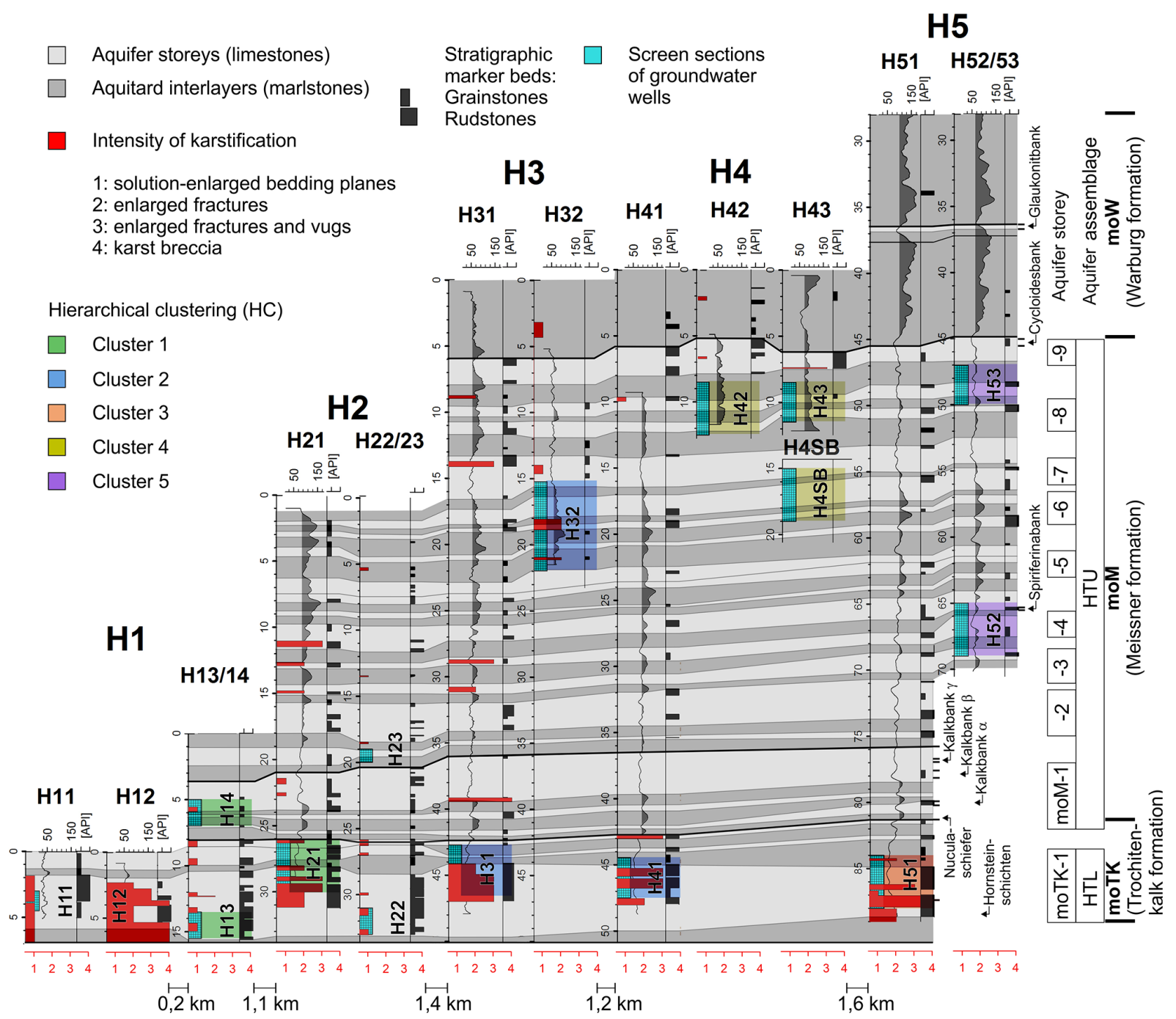

Figure 4. Graphical correlation of marlstone-claystone intervals in gamma-ray logs, biostratigraphic limestone marker beds (grainstones/rudstones) and the intensity of karstification (red bars and red scale bar below: karstification increases in the direction: solutionenlarged bedding planes to karst breccia). The geological aquifer correlation is cross-checked with the hierarchical clustering of hydrochemical parameters.

and also from moM-5/6 well $\mathrm{H} 32$. Groundwater samples from moTK-1 well H51 are plotted in cluster 3. Cluster 4 includes moM-6/7/8 wells H42/43/4SB, while cluster 5 consists of two moM-3/4/8 wells of the same site (H52/53; Fig. 7). Multi-case clustering does not occur. As a result of the PCA using the complete parameter set (Fig. 7a) and the parameter set without redox-sensitive parameters (Fig. 7b), data points fall into very similar groupings compared to the HC. According to the PCA of the complete parameter set, the first two components (PC1 plus PC2) explain $54.9 \%$ (variances of PC1: $34.6 \%$; and PC2: $20.4 \%$ ), and according to the parameter set without redox-sensitive parameters, PC1 plus PC2 explain $62.1 \%$ (variances of $\mathrm{PC} 1: 35.4 \%$; and PC2: $26.8 \%$ ) of the total variability, respectively. For both PCAs, the parameters with the highest factor loads are $\mathrm{Si}^{4+}, \mathrm{K}^{+}$,
$\mathrm{Na}^{+}, \mathrm{HCO}_{3}^{-}$, and $\mathrm{Mg}^{2+}$ for $\mathrm{PC} 1$ and $\mathrm{Sr}^{2+}, \mathrm{SO}_{4}^{2-}, \mathrm{EC} \_25$, and $\mathrm{Cl}^{-}$for $\mathrm{PC} 2$.

The average chemical composition of the five groundwater clusters is significantly different with respect to their physico-chemistry and major ion composition. Cluster 1 shows high $\mathrm{pH}$ and $\mathrm{Eh}$, as well as high concentrations in dissolved $\mathrm{O}_{2}$, TOC and $\mathrm{Ca}^{2+}$. High concentrations in $\mathrm{HCO}_{3}^{-}$, $\mathrm{NO}_{3}^{2-}, \mathrm{TOC}, \mathrm{Cl}^{-}$and $\mathrm{Mg}^{2+}$ are distinctive for cluster 2, whereas cluster 3 is characterized by very high $\mathrm{SO}_{4}^{2-}, \mathrm{Ca}^{2+}$, $\mathrm{Cl}^{-}$, and $\mathrm{Sr}^{2+}$ concentrations in combination with high redox potential and moderate $\mathrm{K}^{+}$and $\mathrm{Na}^{+}$content. Cluster 4 shows very high concentrations in $\mathrm{Fe}^{2+/ 3+}, \mathrm{Mn}^{2+/ 4+}$, TOC, and $\mathrm{Cl}^{-}$in combination with very low redox potential and very low dissolved oxygen. The latter is also applied to clus- 


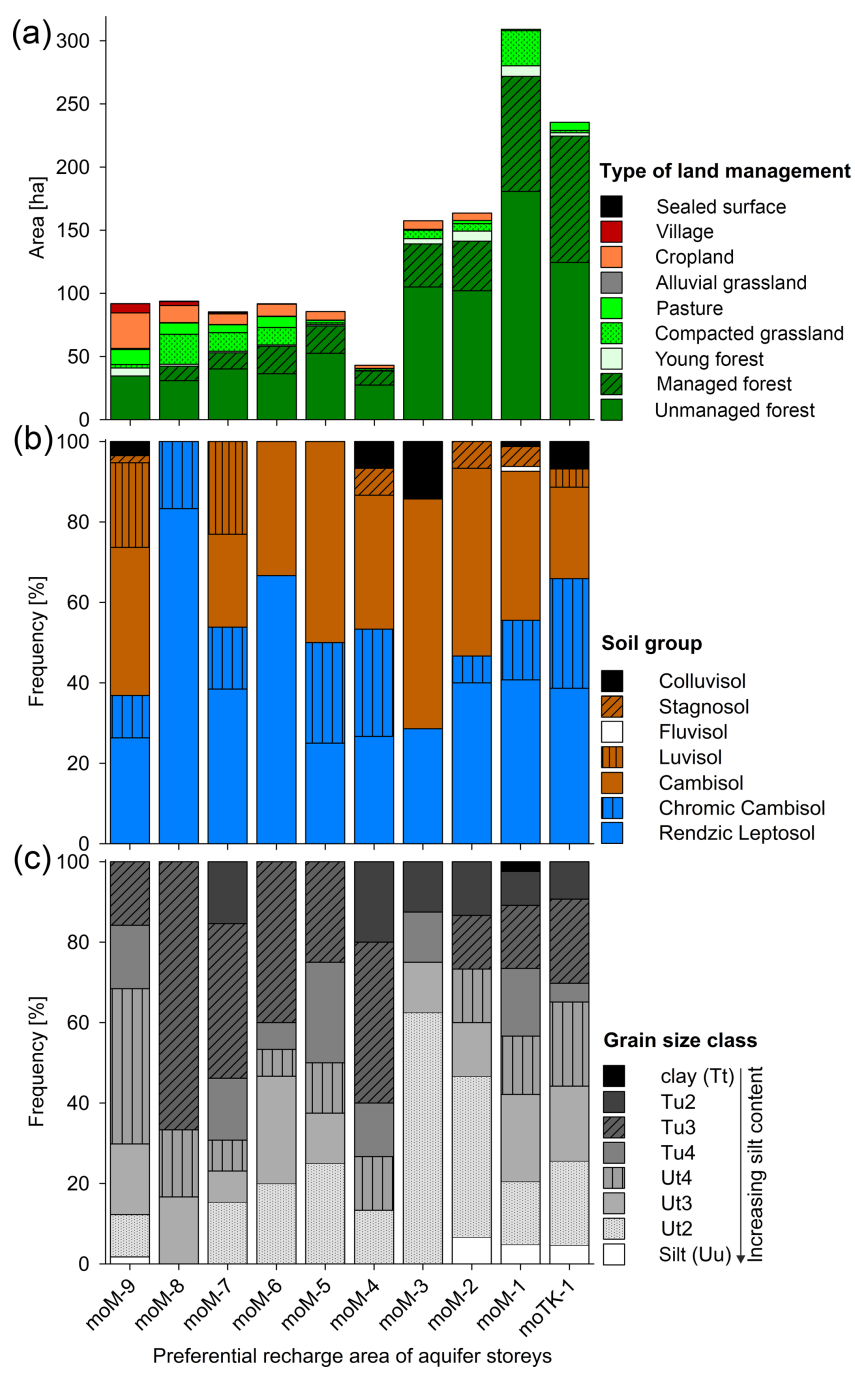

Figure 5. Surface and subsurface properties of the aquifer recharge zones (moTK-1 to moM-9) on the Hainich hillslope. Area sizes are related to the $29 \mathrm{~km}^{2}$ area of this study. (a) Absolute abundances of land management types in the preferential recharge areas of the aquifer storeys. The two basal aquifer storeys are characterized by the largest aquifer outcrop areas and the highest amounts of forest within these areas. Agricultural land management increases towards the higher aquifer storeys (moM-2 to moM-9). (b) Relative abundances of soil groups within the aquifer outcrop zones showing high diversity in all aquifer outcrop zones depending on slope positions and Quaternary loess loam/alluvial clay coverage. (c) Grain size classes of the topsoils and subsoils in the aquifer outcrop zones.

ter 5 , which additionally contains high concentrations in $\mathrm{K}^{+}$, $\mathrm{Na}^{+}$and $\mathrm{Mg}^{2+}$ (Fig. 9).

\subsubsection{Fluctuations of groundwater levels and quality}

Groundwater levels are confined in footslope wells. In the wells of site $\mathrm{H} 5$, groundwater rises to $30 \mathrm{~m}(\mathrm{H} 53), 50 \mathrm{~m}$ (H52) and $70 \mathrm{~m}$ (H51) higher than the base of the screen section. Fluctuations of groundwater levels in our monitor- ing wells range from 1 to $3 \mathrm{~m}$ in the hilltop recharge area (well site H13) to more than $25 \mathrm{~m}$ in the groundwater transit area (well site H5). The groundwater level fluctuations show a strong seasonality, with highest levels in March to April and lowest levels in October to December. Monitoring wells of different sites and screen depths differ in average concentrations of the major solutes. These spatial differences are generally higher than the seasonal fluctuations in the wells. Exceptions to these conditions are marked seasonal fluctuations of $\mathrm{Ca}^{2+}$ (monitoring well $\left.\mathrm{H} 31 / 41\right), \mathrm{Cl}^{-}(\mathrm{H} 52 / 53), \mathrm{K}^{+}$ (H41), $\mathrm{Mg}^{2+}(\mathrm{H} 41), \mathrm{Na}^{+}(\mathrm{H} 31 / 41), \mathrm{Si}^{4+}(\mathrm{H} 41)$ and $\mathrm{SO}_{4}^{2-}$ (H31/41).

\subsubsection{Recharge potential map}

The recharge potential is defined here as a qualitative measure of the probability of infiltration, percolation and groundwater recharge. The maps (Fig. 8) visualize potential spatial variation in infiltration recharge, waiving spatiotemporal variable conditions like precipitation characteristics and antecedent soil moisture. The recharge area maps of two selected aquifer storeys (Fig. 8a and b) show the largest recharge potential for their outcrop areas on the Hainich hillslope. Increasing overburden thickness is accompanied by a drastic decrease in recharge potential towards the NE. With respect to the relief position, the greatest recharge potential is assumed for local valleys and in the extension of sinkhole lineaments, although these areas show increased soil thicknesses. In areas with greater thicknesses of the overburden strata, valleys are considered areas of preferential recharge. A slightly higher recharge potential is assumed for pasture and cropland areas compared to forests. The same holds for the flat summit/culmination and upper slope areas, while the slopes of transverse valleys show greater surface water runoff.

\section{Discussion}

\subsection{Hydrostratigraphy}

\subsubsection{Aquifer structure evaluated by lithology}

The lithologically defined aquifer-aquitard succession in combination with the increase in karstification towards the base, and the preferential presence of groundwater at the base of limestone packages, point to confined aquifers with stratigraphic flow control (Klimchouk and Ford, 2000; Goldscheider and Drew, 2007). As hydraulic heads and chemical groundwater compositions of different aquifers at the same sites (H13/14 (cluster 1); H41/42 (clusters 2 and 4); H51/53 (clusters 3 and 5)) are significantly distinct, vertical communication between aquifer storeys is highly reduced. Thus we interpret the thin aquifer beds as confined, "sandwich flow type" aquifers (term: White, 1969; Klimchouk, 2005) which are interbedded with confining aquitards. The assumed lat- 
(a)

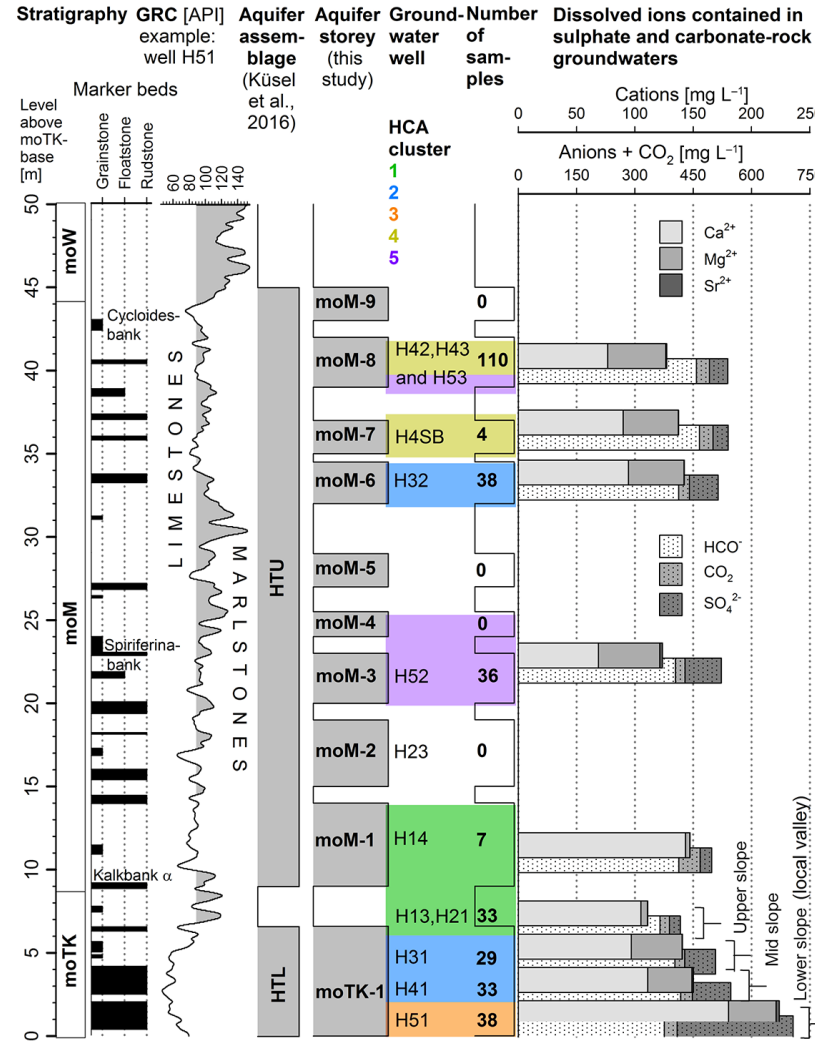

(b)

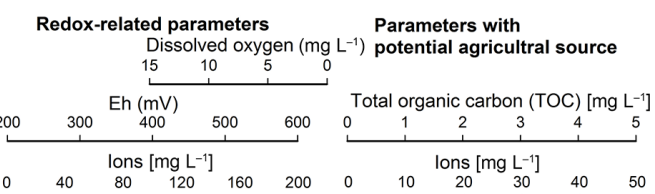

(c)

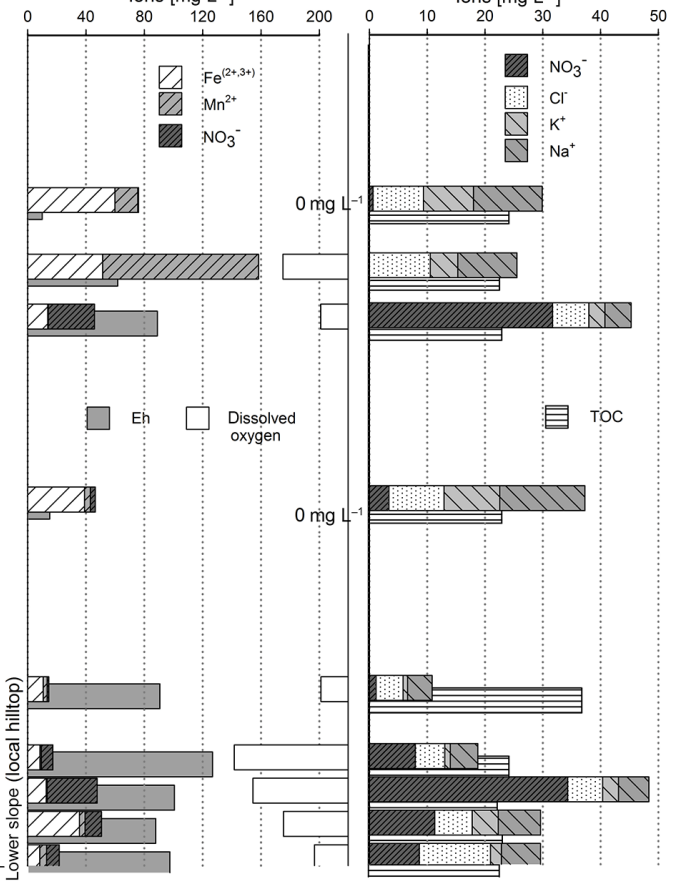

Figure 6. Stratigraphic succession of the Upper Muschelkalk with stratigraphic marker beds (a), a gamma-ray log, aquifer assemblages HTL/HTU, aquifer storeys moTK-1 to moM-9 and the average chemical compositions of monitored groundwater (a: ions related to carbonate/sulfate minerals; b: redox-sensitive ions; $\mathbf{c}$ : ions which are potentially related to the type of land management). The colour code of the hierarchical clusters is identical to Fig. 4.

(a)

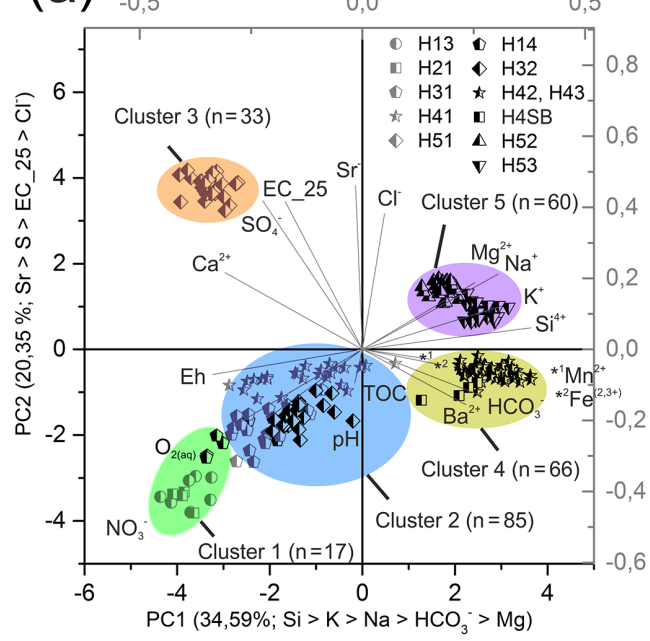

(b)

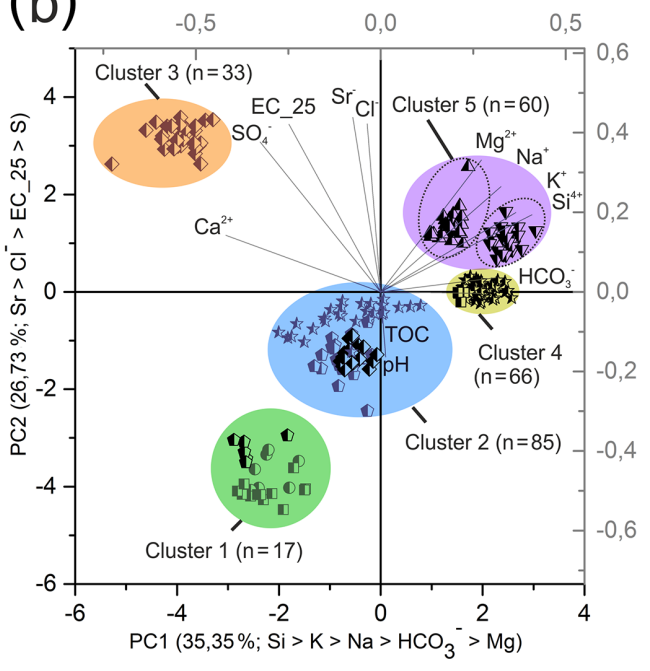

Figure 7. Principal component analysis (PCA) biplot for the complete parameter set (a) and for the limited parameter set (b) without redoxrelated parameters. Five clusters can be distinguished in both parameter sets. Samples within the clusters are identical for both PCA plots. Factor loads for PC1 and PC2 are displayed as labels of the $x / y$-axis as well as the sequence of factor loads for individual components. The colour code of the hierarchical clusters is identical to Fig. 4. 


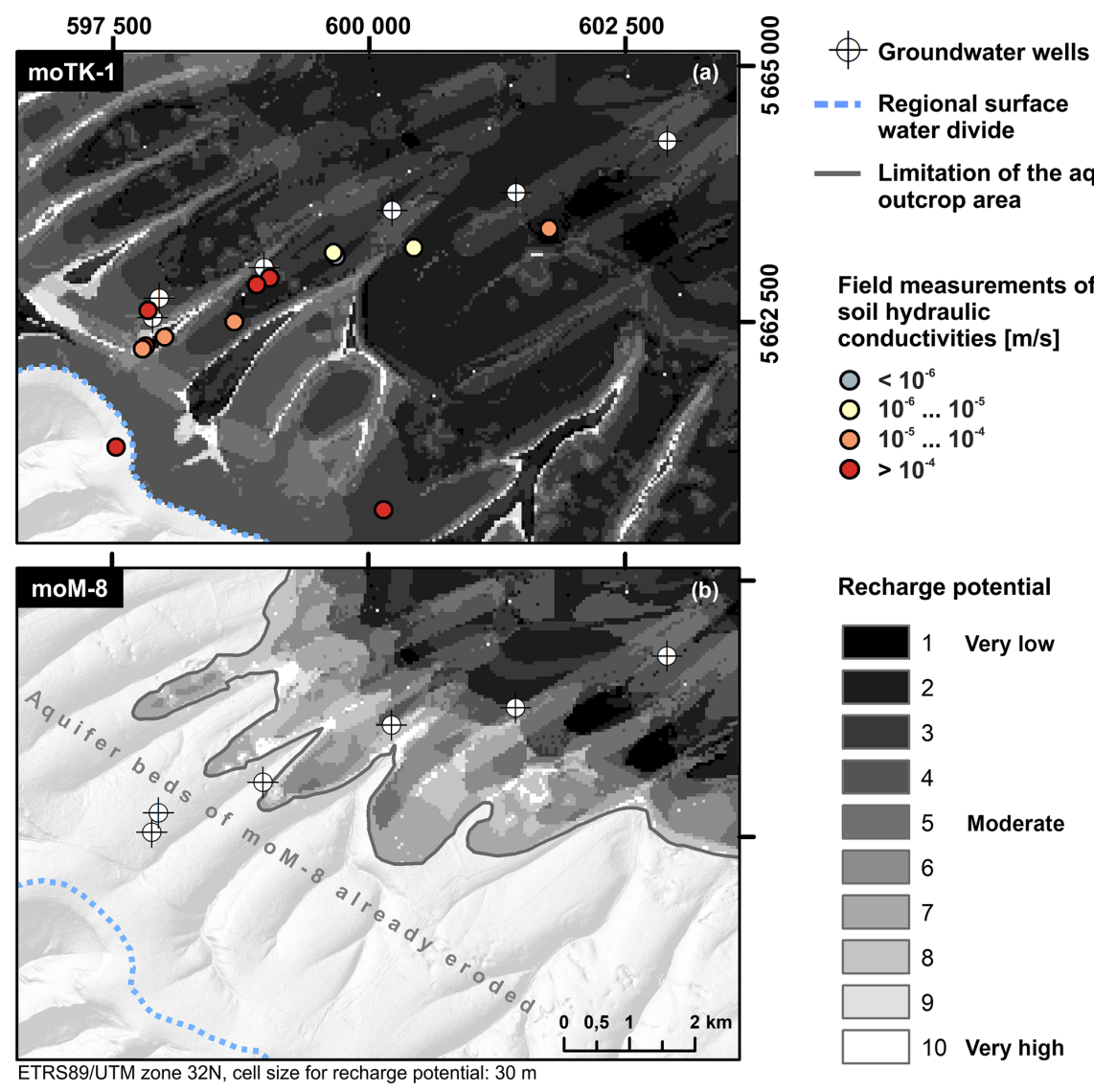

Figure 8. Recharge potential maps for the two contrasting aquifer storeys moTK-1 (a) and moM-8 (b). The recharge potential is a qualitative indicator for infiltration and percolation towards selected aquifer storeys: the brighter the output colour, the higher the recharge potential. Aquifer outcrop zones show the highest recharge potentials followed by sinkhole lineaments and (NE-SW orientated) transverse valleys. The recharge potential decreases drastically with increasing thickness of overburden strata towards the NE. Data points of field measurements are displayed in the upper map (moTK-1 recharge potential) and are colour-coded with respect to their soil hydraulic conductivity. Data sources: DEM@ GeoBasisDE/TLVermGeo, gen. no.: 7/2016.

eral continuity of aquifers and aquitards results in a "layercake" aquifer architecture which has been demonstrated for the Upper Muschelkalk of central Europe (Aigner, 1982, 1985; Merz, 1987; Simon, 1997; Borkhataria et al., 2005). Secondary mineralizations, which indicate groundwater flow (for instance Liesegang banding), occur on limestone fracture walls. Fracturing of aquifer rocks increases close to the (NE-SW striking) fault zones (Hoppe, 1962) and karstification follows the network of faults (Goldscheider and Drew, 2007). Red and brown iron and manganese oxides on upper to midslope fractures (H1/2/3; clusters 1 and 2$)$ indicate temporarily unsaturated conditions, whereas green/grey fracture minerals in the footslope domains ( $\mathrm{H} 4 / \mathrm{H} 5$; clusters 4 and 5) point to permanently water-saturated conditions due to the lack of oxidized $\mathrm{Fe} / \mathrm{Mn}$ minerals. Corrosion occurs in the form of intrastratal karstification, i.e. one or more layers of soluble strata are covered or sandwiched between insoluble beds (Palmer, 1995). Karstification is consistently high in the thick-bedded aquifer storey (moTK-1) and less pronounced in thin-bedded aquifer storeys (moM-1/4/5/6; Fig. 4) as the bed thickness controls the continuity, spacing and width of joints (Goldscheider and Drew, 2007). In general, the lithological definition of hydrostratigraphy allows a structuring with a high spatial resolution.

\subsubsection{Evaluation of groundwater chemistry}

Stratigraphically deep aquifers in summit positions are grouped in cluster 1 (aquifer storeys moTK-1 and moM1). Cluster 2 (moTK-1 and moM-5+6) encompasses deep and stratigraphically intermediate aquifer storeys in midslope positions and cluster 3 (moTK-1) a deep aquifer storey in the footslope position. Shallow aquifer storeys (moM-6/7/8) in the midslope position within a local valley are grouped in cluster 4 and intermediately deep aquifer storeys (moM$3 / 4 / 8$ ) are grouped in cluster 5 . According to this grouping, the slope position and the depth below the surface is important, likewise to the depth level within the hydrostratigraphy (the aquifer storey). 
PCA using the complete parameter set (a) infers that each aquifer storey contains more than one type of groundwater chemistry (Fig. 7). By contrast, the PCA (b) carried out with the limited parameter set (without redox-related parameters) shows a clear separation of moTK-1 and moM-1-9 aquifer storeys (except for cluster 2). According to the PCA, cluster 1 encompasses high factor charges in $\mathrm{pH}, \mathrm{Eh}, \mathrm{O}_{2}$, and $\mathrm{NO}_{3}^{-}$and low factor charges in $\mathrm{Mg}^{2+}, \mathrm{Na}^{+}, \mathrm{K}^{+}$, and $\mathrm{Si}^{4+}$. The same is less markedly applied for cluster 2 , whereas factor charges in cluster 5 point in opposite directions. We explain this linear trend of cluster grouping as a consequence of a trend of the chemical evolution from summit wells (cluster 1) with small recharge areas and shallow aquifers towards midslope (cluster 2) and footslope (cluster 5) passages with thicker overburden strata. The latter are affected by minor surface influences and longer groundwater travel times/residence times within the bedrock. Data points of different aquifer storeys are grouped (but within the clusters), and slope position and aquifer depths seem to be more important for groundwater chemistry than the position in hydrostratigraphy, here. Apart from this trend, cluster 3, which is limited to the deepest well (in footslope position), exhibits high factor charges in $\mathrm{Ca}^{2+}, \mathrm{SO}_{4}^{2-}, \mathrm{EC}_{2} 25$, and $\mathrm{Sr}^{2+}$ and low charges in $\mathrm{Ba}^{2+}, \mathrm{HCO}_{3}^{-}, \mathrm{Fe}^{3 / 4+}$, and $\mathrm{Mn}^{2 / 4+}$, whereas cluster 4 (limited to shallow wells in midslope position) shows opposite factor charges for these parameters. In general, clusters are grouped in a line of chemical development and by oxic/anoxic conditions and different mineralizations, depending on the position in aquifer stratigraphy.

\subsubsection{Modes of groundwater flow}

Within the aquifer-aquitard sandwich, fast conduit groundwater flow, which is typical for karstified carbonate rocks (Wong et al., 2012), likely takes place in the moTK-1 and partially in the moM-1 aquifer storeys, whereas slow diffusion in slightly fractured, thin aquifers beds is anticipated in the moM-2 to moM-9 aquifer storeys. Confined diffuse flow is considered laminar and takes place in interparticle pores and fractures of dense limestones with low primary porosity (Smart and Hobbs, 1986). This results in the well oxygenated moTK-1 and moM-1 groundwaters and a significant oxygen consumption/deficiency (coupled to the mobility of $\mathrm{Fe}^{2+}$ and $\mathrm{Mn}^{2+}$ ions and the low mobility of $\mathrm{NO}_{3}^{-}$and $\mathrm{SO}_{4}^{-}$ions) in the moM-2 to moM-9 groundwater, resulting in completely different milieu conditions for the biogeochemical processes and for the life in the subsurface as well.

\subsection{Surface-subsurface connectivity}

Potential zones for interactions between surface and subsurface waters are the outcrop areas of the aquifers, incised valleys (cutting into the stratigraphic succession), springs and surface karst phenomena. Nearby faults and valleys, an increased number of additional non-strata-bound, connected fractures that provide pathways for pronounced and preferential fluid flow (Meier et al., 2015) are likely.

\subsubsection{Preferential recharge areas}

As a typical feature of aquifer-aquitard alternations in a tilted hillslope setting, preferential recharge takes place at the aquifer outcrop zones (Andreu et al., 2011; Fig. 2a). Based on the tectonically tilted and subsequently exhumed hillslope, the main aquifer recharge area is situated in the upper hillslope/summit area, which is covered by forest with very low anthropogenic impact. A predictable geological structure allows a general tracking of flow paths from the recharge to discharge areas. The second route for preferential recharge is related to the lines of caprock sinkhole lineaments, which can be tracked over more than $4 \mathrm{~km}$ in the midslope between transect locations $\mathrm{H} 2 / 3$ and $\mathrm{H} 4$. The origin of these sinkholes does not lie in the karstification of the Upper Muschelkalk strata itself, as the combination of aquifer fracture networks (tight conduits) and stabilizing, insoluble aquitard beds does not cause sufficient mass deficits that would allow hanging wall collapses. Here, caprock sinkholes are related to mass deficits by subrosion in the underlying evaporite rocks with gypsum and halite (Mempel, 1939; Malcher, 2014). As caprock sinkholes are arranged in lineaments (Fig. 2a) parallel to regionally known fault orientations, it is very likely that they are coupled to the penetration of surface-subsurface water at fracture zones (compare to Smart and Hobbs, 1986; Worthington, 1999; Klimchouk, 2005) that promote preferential recharge (Smart and Hobbs, 1986; Suschka, 2007). Although dissolution of soluble rocks is limited within the target aquifers of this study, it is reasonable that collapse structures are accompanied by enhanced rock fracturing and permeability.

\subsubsection{Influences of soils in the recharge area}

The spatial distribution of the soil groups reflects the outcrop zones of limestones/marlstones (Greitzke and Fiedler, 1996; Brandtner, 1997; Rau and Unger, 1997) and the succession of aquifer storeys in the summit/shoulder area of the hillslope which exhibits little Quaternary rock coverage and thin soils (Rendzic Leptosol, Chromic Cambisol) with favourable infiltration properties in the aquifer outcrop areas of moTK-1 and moM-1/6/8. Thicker relictic Chromic Cambisols which are formed by intensive decarbonatization (Rau and Unger, 1997; AG Boden, 2005) are restricted to accumulations in former depressions (i.e. caprock sinkholes) in shoulder regions of the hillslope (moTK-1 and moM-1 outcrops). Besides these depressions, Chromic Cambisols with low hydraulic conductivities are typically the subsoil layer of sequences with two layer superimposed soils, resulting in lateral soil interflow (Ali et al., 2011) as is observed in our shoulder and midslope regions during the measurement of soil hydraulic conductivities. Soils on unfractured marl- 
stone/claystone aquitards are typically Calcaric Regosols and Stagnosols with low hydraulic conductivities of both soils and parent rocks. According to our data set, soil thickness is primarily controlled by the slope gradient of transverse valleys with increasing soil thickness and water storage options towards the centre of valleys. As a result of the increasing coverage of parent rocks by loess loam from the regional midslope to the footslope (related to solifluction of windblown dust; Kleber, 1991; Bullmann, 2010), loess loam becomes the dominating soil substratum in the outcrop areas of aquifer storeys moM 7/8/9. In this area, Luvisols cover local ridges and Luvisol-Stagnosol transitions (related to the continuous vertical clay relocation, Rau and Unger, 1997) cover local valleys, whereas older caprock sinkholes are either filled by Colluvisols or with loess loam, leading to either poor or very good infiltration/recharge properties. In the same context, Bachmair et al. (2009) consider the role of micro-depressions in soils as one of the major factors in preferential recharge.

Although median grain size, grain size sorting and the standard deviation of grain size fractions are comparable in all soils, "carbonate series soils" (Rendzic Leptosol and Chromic Cambisol) offer lower hydraulic conductivities than "siliceous series soils" (Cambisol, Luvisol, Stagnosol) by 1 order of magnitude. Soil hydraulic conductivities $\left(K_{\mathrm{S}}\right)$ are uncorrelated with soil texture properties. For this reason a linear transfer function ( $K_{\mathrm{S}}$ vs. median grain size or grain size category) for extending the $16 K_{\mathrm{S}}$ measurements to the 271 mapped soil profiles was not possible with the actual data set. A low correlation between $K_{\mathrm{s}}$ and texture is related to strong influences of soil structure and aggregation (Totsche et al., 2017) rather than texture on $K_{\mathrm{s}}$. Structural parameters are for instance the content and proportion of macro- and micro-aggregates, a hierarchical aggregate system, the presence and frequency of secondary pores and anthropogenic changes like former plough traces or traces of forestry machines. Bachmair et al. (2009) for instance identify tillage-related macropores as a main factor in deep infiltration into cropland soils, whereas litter layers inhibit infiltration into forest soils. Moreover, preferential infiltration through biomacropores (i.e. earthworm borrows, root channels) that bypass the soil matrix are of great significance in aggregated and argillaceous soils with low matrix conductivity for the infiltration during heavy rain events (Deurer et al., 2003; Weiler and Naef, 2003; Blouin et al., 2013). Klaus et al. (2013) identify vertical macropores of anecic earthworms as a major flow control in a hillslope tile drain system. Wienhöfer and Zehe (2014) additionally consider loose, litter-rich topsoils, lateral preferential pathways, preferential pathways at the soil-bedrock surface and bedrock topography.

\subsubsection{Influences of land management in the recharge area on groundwater quality}

The forest areas as a source of groundwater from nearcatchment summit/shoulder wells are confirmed by their aquifer outcrop areas (moTK-1, moM-1) within the managed (and partly unmanaged) forest. In contrast, we detected potentially agriculture-related substances $\left(\mathrm{NO}_{3}^{-}, \mathrm{K}^{+}, \mathrm{Cl}^{-}\right)$ in the wells drilled to all aquifer storeys in midslope location wells (H31/41), although these groundwater types are recharged mainly within the forest (up to $96.5 \%$ forest). These surface signals are interpreted as being related to the cropland and village areas within the preferential recharge zones with sinkhole lineaments. Anoxic groundwaters in aquifers (moM8/9) partially recharged from outcrop areas with agricultural and village land use are likely due to microbial oxygen depletion resulting from the degradation of organic carbon or oxidation of inorganic electron donors. For shallow wells in valleys (H42/43/4SB), lateral soil water inflow with high organic/fertilizer load towards the valley provides an alternative way for the enhancement of oxygen depletion. Much lower $\mathrm{NO}_{3}^{-}, \mathrm{K}^{+}$, and $\mathrm{Cl}^{-}$concentrations in the footslope wells (H52/53) are likely a consequence of the argillaceous caprocks that increase in thickness towards the footslope.

\subsubsection{Utilization of the recharge potential for interpreting groundwater quality}

Due to the recharge potential map (Fig. 8), thick, limestonedominated aquifer storeys in the deeper sections of the hydrostratigraphy (i.e. moTK-1) are mainly recharged in their outcrop areas and subordinarily in sinkhole lineaments and transverse valleys. Within these areas, $\mathrm{Ah}-\mathrm{Cv}$ soils (i.e. Rendzic Leptosol) and fractured limestone bedrocks offer the highest recharge potential. A drastic decrease in recharge potential with increasing overburden strata is confirmed by low concentrations in surface-related substances (i.e. $\mathrm{NO}_{3}^{-} \cdot \mathrm{Cl}^{-}$, $\mathrm{K}^{+}$) in well sites $\mathrm{H} 1 / 2 / 4 / 5$ for the aquifer storey moTK-1. Increasing concentrations of ions, which are related to the dissolution of the carbonate (aquifer) bedrock $\left(\mathrm{Ca}^{2+}, \mathrm{Mg}^{2+}\right.$, $\mathrm{HCO}_{3}^{-}$and $\mathrm{Sr}^{2+}$ ) point to a chemical evolution of groundwater in the direction of discharge (H1 to $\mathrm{H} 5)$. A moderate to high recharge potential combined with cropland/pasture areas) in the recharge direction of site $\mathrm{H} 3$ is reflected by increased concentrations in TOC, $\mathrm{NO}_{3}^{-}, \mathrm{Cl}^{-}, \mathrm{K}^{+}, \mathrm{Na}^{+}$and $\mathrm{O}_{2}$ (Figs. 6 and 9). Aquifer storeys with thin-bedded limestonemarlstone alternations (i.e. moM-8, Fig. 9) generally show a lower recharge potential in their aquifer outcrop zones compared to thick, limestone-dominated aquifers (moTK1), which is related to thicker soils and a high marlstonelimestone ratio. This is reflected in the groundwater quality of moM-8 wells (H42/43/53) with low Eh and low concentrations in $\mathrm{O}_{2}$, pointing to slow flow velocities and long 
residence time within the argillaceous soils and marlstonedominated and thinly fractured bedrocks.

\subsubsection{Flow directions}

The four modes of presumed groundwater flow are (1) vertical percolation, (2) bedding-parallel flow, (3) descending, cross-formational flow and (4) ascending cross-formational flow. (1) Vertical percolation through the soils and the unsaturated zone takes place in the whole Hainich CZE catchment area, following diffuse/non-point infiltration. As the aquitard interbeds highly reduce the vertical flow connections, outcrop zones of the aquifer storeys as well as caprock sinkholes act as important preferential infiltration pathways which are typical for hillslope recharge zones. Since caprock sinkholes remain dry, even directly after precipitation events, high infiltration rates can be assumed for these structures. (2) An undisturbed sequence of aquifers and aquitards with constant bed characteristics, comparable groundwater chemistry within the same aquifer storey and the high pressure heads (well H51/52/53: 70/50/20 $\mathrm{m}$ rise within the well pipe) are interpreted to indicate bedding-parallel flow (stratigraphic flow control; Goldscheider, 2005) in the groundwater transit zone. This is supported by the spatial variation of groundwater chemistry within the same aquifer storey (i.e. an increase in $\mathrm{K}^{+}, \mathrm{Na}^{+}, \mathrm{Mg}^{2+}$ and $\mathrm{Si}^{4+}$ within moM-8 from well sites $\mathrm{H} 4$ to $\mathrm{H} 5$ ), given a cut-off from surface influences there. Also, the combination of saturated conditions within the shallow storey and temporarily unsaturated conditions within the lower aquifer storey in well site H3 points to highly reduced vertical flow. Bedding-parallel flow is also supposed for fractures with small fault displacements that do not exceed the thickness of the interbedded aquitard (compare to Goldscheider and Drew, 2007). (3) Zones with enhanced fracture indices (fractures / $\mathrm{m}$ drill core) in well site $\mathrm{H} 3$ as well as consistent $\mathrm{Fe} / \mathrm{Mn}$-oxide fracture walls in all aquifer storeys of this site point to a quick and cross-formational descending flow of oxygenated groundwater (thus with low $\mathrm{Fe} / \mathrm{Mn}$ mobility; Hem, 1985) via vertical master joints (term: Dreybrodt, 1988; Ford and Williams, 2007) close to potential fracture zones. This is supported by higher concentrations in $\mathrm{Na}^{+}, \mathrm{K}^{+}, \mathrm{NO}_{3}^{-}, \mathrm{Cl}^{-}$and TOC in the deeper site of $\mathrm{H} 3 \mathrm{com}-$ pared to the shallower well of this site, related to agriculture and fertilizing (Matthess, 1994; Kunkel et al., 2004). Crossformational descending flow in shattered or fractured rocks is assumed to take place in fracture zones (Worthington, 1999; Goldscheider and Drew, 2007), tracked by lineaments of caprock sinkholes (Mempel, 1939; Hoppe, 1962; Smart and Hobbs, 1986; Jordan and Weder, 1995). (4) Groundwater chemistry of footslope well H51 (screen base at the base of the moTK-1 aquifer) bears a combination of high concentrations in $\mathrm{Ca}^{2+}, \mathrm{SO}_{4}^{2-}, \mathrm{Sr}^{2+}$, and $\mathrm{Cl}^{-}$(and $\mathrm{SO}_{4}^{2-} / \mathrm{HCO}_{3}^{-}$ ratios) and low concentrations in $\mathrm{K}^{+}, \mathrm{Na}^{+}$, and $\mathrm{NO}_{3}^{-}$that points to a non-surface import of sulfate (chloride) groundwater due to dissolution of evaporite rocks (Edmunds and
Smedley, 2000). The location of this lowermost aquifer storey directly above dolomite, gypsum and halite beds (Middle Muschelkalk; Jordan and Weder, 1995) points to ascending cross-formational groundwater flow (Garleb, 2002; Völker and Völker, 2002). The ascent of groundwater, which is well known for artesian settings (Klimchouk, 2005), could be related to hydraulically confined conditions as measured for site $\mathrm{H} 5$ and the assessed groundwater flow crossing a sinkhole lineament between well sites H4 and H5 (Fig. 10). Alternatively, the ascent of Middle Muschelkalk groundwaters is probably related to a decrease in permeability within the Middle Muschelkalk aquifers, as subrosion of sulfate rocks (succeeding from the summit to the footslope region) has not reached the groundwater transit zone yet, resulting in the presence of low permeable sulfate rocks and an ascent of groundwaters discharging the Middle Muschelkalk (Hoppe and Seidel, 1974; Garleb, 2002).

\subsection{Controls on groundwater quality and groundwater provenance}

Cluster 1 comprises the shallow to intermediate deep moTK$1(\mathrm{H} 13 / 21)$ and moM-1 (H14) wells with base depths of screen sections between 7.0 and $30.5 \mathrm{~m}$. Groundwater chemistry with high $\mathrm{HCO}_{3}^{-}$and $\mathrm{Ca}^{2+}$ as well as low $\mathrm{Mg}^{2+}, \mathrm{SO}_{4}^{2-}$, $\mathrm{Na}^{+}, \mathrm{K}^{+}$, and $\mathrm{Si}^{4+}$ concentrations (Fig. 9) correspond to the pure calcite limestone $\left(\mathrm{CaCO}_{3}\right)$ aquifer lithology. Low concentrations in $\mathrm{Cl}^{-}, \mathrm{K}^{+}, \mathrm{Na}^{+}$, and $\mathrm{Mg}^{2+}$ are related to parts of the catchment area that are exclusively used as forest and to soils (mainly Rendzic Leptosols) with high hydraulic conductivities and with little clay content, resulting in short residence times of water in soils. Relatively high concentrations in TOC are linked to little organic degradation due to short travel times. Fast infiltration also arises from aquifer outcrop zones in culmination areas, allowing a high ratio of infiltration vs. lateral soil interflow. According to the PCA, cluster 1 wells could be interpreted as one end-member at the beginning of a "groundwater development series". Generally, groundwater compositions in summit regions of hillslopes are comparable to the composition of the bedrock. Surface signals (i.e. soil or vegetation-derived organic carbon) can be traced more clearly due to little organic degradation (and low filtering) along the flow path by the soils and bedrock pores/fractures.

Cluster 2 encompasses moderately deep moTK-1 wells (H31/41) and one moM-5/6 well (H32) with base depths of screen sections between 22.0 and $47.5 \mathrm{~m}$. The hydrochemistry with moderate concentrations in $\mathrm{Ca}^{2+}, \mathrm{Mg}^{2+}$, and $\mathrm{SO}_{4}^{2-}$ and low $\mathrm{K}^{+}$and $\mathrm{Na}^{+}$as well as high $\mathrm{Mg} / \mathrm{Ca}$ ratios is not linked to the pure calcite limestones (moTK1) or the calcite/illite/kaolinite/chlorite mineral composition (moM-5/6) and requires an external source of $\mathrm{Mg}^{2+}$. Nitrate and TOC contents are higher than expected by the forest (moTK-1)/forest-dominated type of land management (moM-5/6) in the aquifer outcrop zones and are likely ex- 


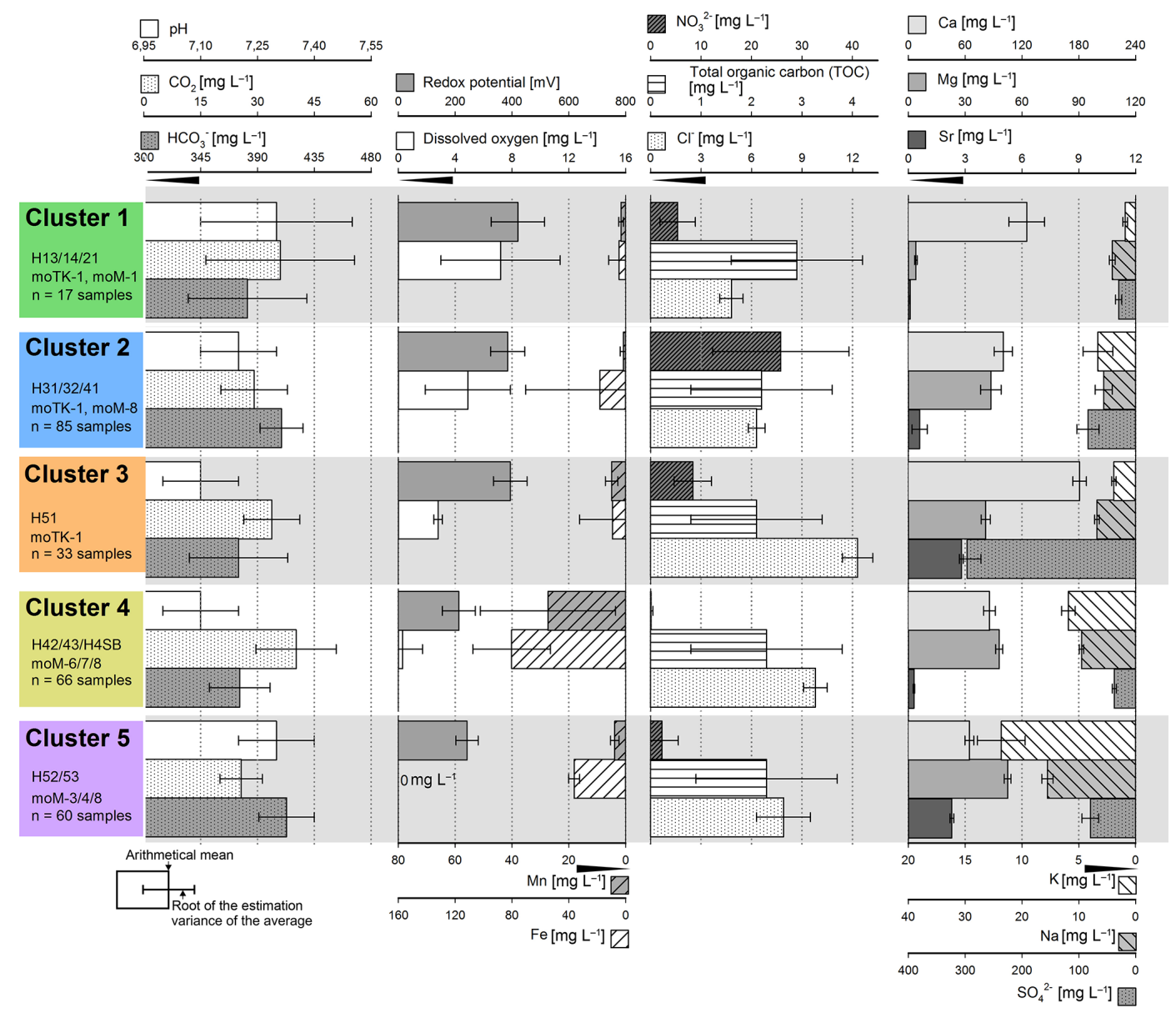

Figure 9. Average groundwater chemistry of hierarchical clusters 1-5 (left: groundwater wells and aquifer storeys within the clusters). First column: parameters related to the carbonate- $\mathrm{CO}_{2}$ equilibrum; second column: dissolved $\mathrm{O}_{2}$, redox potential and redox-sensitive ions; third column: ions which are potentially related to land management; fourth column: ions related to the dissolution of either carbonate/sulfate or clay minerals. The colour code of hierarchical clusters is identical to Fig. 4.

plained by cropland/pasture in a sinkhole lineament in the recharge zones of sites H3/4. Oxygenated groundwater in both aquifer storeys (thus with low Fe/Mn mobility; Hem, 1985) and a high degree of rock fracturing and fracture mineralization with Fe-/Mn-oxide minerals (aquifer storeys moM-9/8/7 and 6), point to a vertical penetration with nearsurface groundwater via fracture zones through all aquifer storeys. Enhanced concentrations in $\mathrm{Na}^{+}, \mathrm{K}^{+}, \mathrm{NO}_{3}^{-}, \mathrm{Cl}^{-}$and TOC (Fig. 9) are likely related to agriculture and fertilizing (Matthess, 1994; Kunkel et al., 2004) around the sinkhole lineaments. As nitrate, which is generally derived from agricultural fertilizers (Agrawal et al., 1999; Jeong, 2001), is still present in the deep aquifer waters of site $\mathrm{H} 3$, vertical bypassing through master joints (term: Dreybrodt, 1988; Ford and Williams, 2007) must be faster than the denitrification process. Quick infiltration is here mostly related to the preferential sinkhole recharge, as the soils (Luvisol/Cambisol, both with low-conductive subsoils and a high degree of lateral soil interflow) in the outcrop zones bear only moderate to poor soil hydraulic conductivities. In general, groundwater in the discharge of exceptionally highly conductive preferential recharge spots can reflect surface signals, even in stratified aquifer-aquitard successions. These zones are therefore suggested to be of uppermost importance for groundwater protection.

Cluster 3 contains groundwater of the deepest moTK-1 well (screen base $88 \mathrm{~m}$ ) drilled to a cropland plot in the footslope area. As is discussed in Sect. 5.2.5, ascending sulfatic groundwater is likely responsible for the $\mathrm{SO}_{4}^{2-}-\mathrm{HCO}_{3}^{-}$type of groundwater. High chloride concentration is interpreted with a long groundwater travel distance. Very weak surface signals (in the form of low nitrate and TOC concentrations) attest to the inhibition of vertical infiltration by aquitards and a likely result from long groundwater travel distances (high residence time) from the forest recharge zone of the moTK-1 aquifer. However, high groundwater oxygen concentration in more than $5 \mathrm{~km}$ from the capture zones requires a very quick oxygen supply by more rapid flow events. In general, deeper 


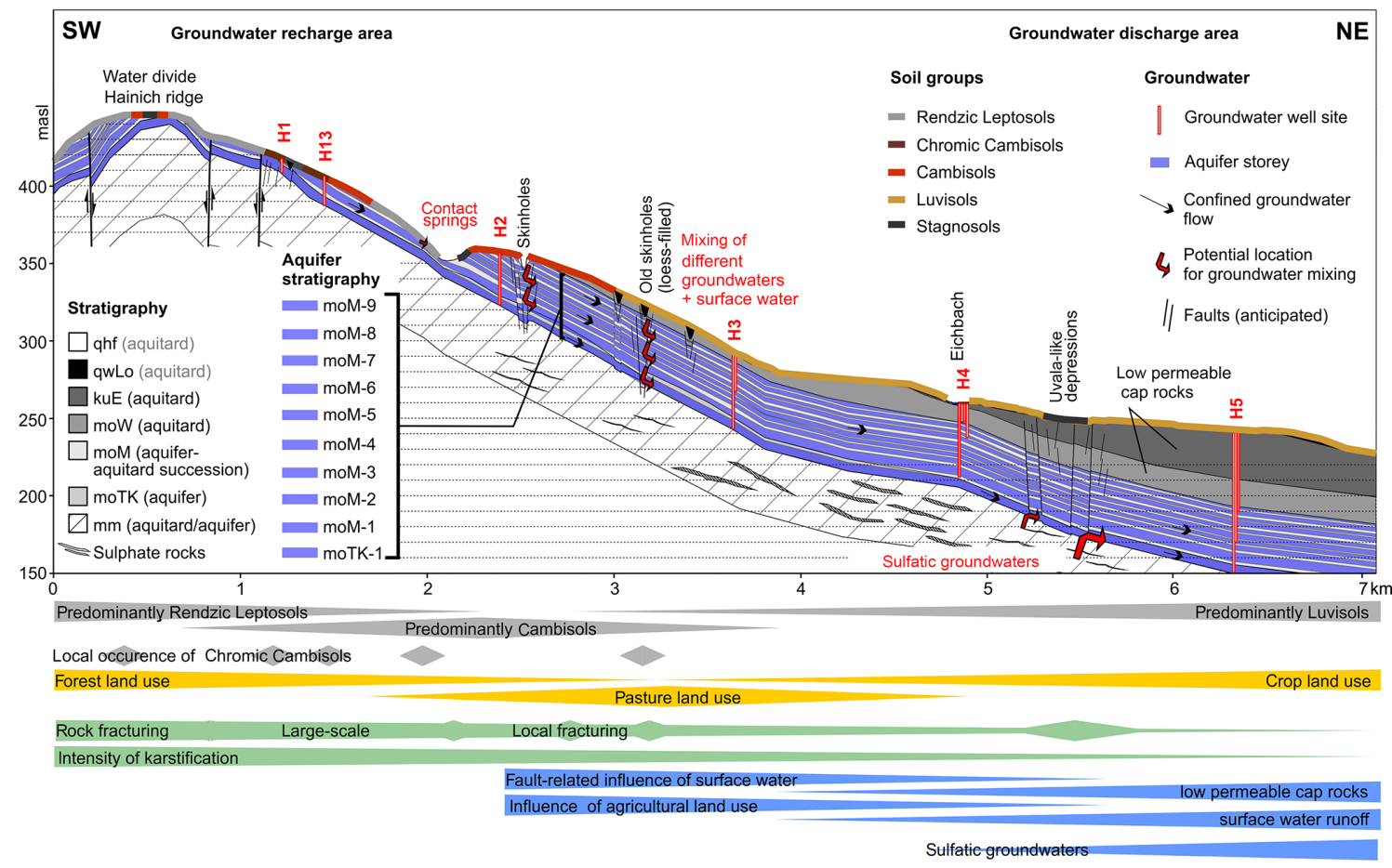

Figure 10. Conceptual cross section of the Hainich hillslope showing the overall geological structure with the 10 aquifer storeys illustrating preferential aquifer recharge zones in the summit to midslope region as well as the discharge direction. Lineaments of caprock sinkholes crossing the potential groundwater flowpath represent potential zones for descending or ascending cross-formational flow and also the mixing of different types of groundwater.

groundwater in the transit zone may bear surface signals, if flow velocities are great enough for transporting young groundwater into the subsurface. This is applied for the more karstified aquifer storeys in aquifer-aquitard successions.

Cluster 4 includes groundwater of the shallow moM6/7/8 wells H42/43/H4SB with screen depths in 11.5 to $19.0 \mathrm{~m}$. Low-conductive alluvial cover sediments reduce vertical infiltration drastically. High $\mathrm{HCO}_{3}^{-}$and low $\mathrm{Na}^{+}$, $\mathrm{K}^{+}, \mathrm{Si}^{4+}$, and $\mathrm{Sr}^{2+}$ concentrations as well as the moderately high $\mathrm{Mg} / \mathrm{Ca}$ ratio in the groundwater reflect the calcite and dolomite aquifer mineralogy. High $\mathrm{Fe}^{(2+\text { and } 3+)}$, $\mathrm{Mn}^{(2+}$ and $\left.4+\right)$ and low $\mathrm{SO}_{4}^{2-}$ concentrations correspond to a low redox potential and the absence of dissolved oxygen, controlling the mobility of these ions (Hem, 1985; Hsu et al., 2010). Although the aquifer catchment of moM-6/7/8 is of a mixed forest/agriculture/village type, TOC and $\mathrm{NO}_{3}^{-}$concentrations are low due to the consumption of organic matter and the denitrification under anoxic conditions (Agrawal et al., 1999). Relatively high $\mathrm{Cl}^{-}, \mathrm{K}^{+}$concentrations are probably remnants of agriculture-/village-related surface signals. The discrepancy of a close distance to the recharge area and the low oxygen content could be explained by low hydraulic subsoil conductivities of the moM-7 outcrop area (Luvisols, Stagnosols, Cambisols) and very narrow fractures in the aquifer rocks of moM-8. Generally, aquifer confinements in valleys of hillslope aquifers could result in low aquifer qual- ity, directly depending on the fracture sizes and soil hydraulic conductivities.

Cluster 5 encompasses groundwater from deep (50.0$69.0 \mathrm{~m}$ screen depths) aquifer storeys moM-3/4/8 (wells H52/53) which are covered by very thick ( $>40 \mathrm{~m}$ ), low permeable cover strata (Erfurt formation, Warburg formation). High $\mathrm{K}^{+}, \mathrm{Na}^{+}, \mathrm{Mg}^{2+}$ and $\mathrm{Si}^{4+}$ concentrations correspond to long residence times of groundwater (Bakalowicz, 1994; Khan and Umar, 2010) in marlstone-limestone successions due to the distant $(>3 \mathrm{~km})$ recharge zones. If the grouping of groundwater types in the PCA represents a "chemical evolution series", then cluster 5 stands for the most developed/oldest groundwater. In general, caprock-covered footslope aquifers with narrow fractures likely contain more developed groundwater that mostly reflects subsurface influences and fewer surface influences (i.e. in comparison with more conductive aquifers of the same well site $-\mathrm{H} 5$ ).

\subsection{Assessment of vulnerability factors}

The configuration of the aquifer system in the hillslope setting also controls the groundwater resource vulnerability. With our multi-method investigation of the different subsurface compartments, we also revealed factors of the areas' intrinsic vulnerability. Characteristics of intrinsic vulnerability are solely controlled by hydrogeological properties 
of the aquifer and overburden (Vrba and Zoporozec, 1994), and integrate the inaccessibility (i.e. by low-permeable cover strata) of the saturated zone and the attenuation capacity (retention, turnover) of the overburden (Adams and Foster, 1992).

The stacking of aquifers/aquitards, the coverage with caprocks and the lateral continuity of strata reduce the overall dominating disperse infiltration and, thus, the intrinsic vulnerability. Threats to single aquifer storeys or assemblages are predominantly related to fractures/faults (valleys) or karst phenomena bypassing the protective cover of soils and unsaturated zones (Fig. 8). A moderate degree of physical filtering by the narrow fractures, which are the predominant flow paths, is assumed. Also, the claystone and marlstone interlayers bear a certain filtering of contaminants by retention. The preferential recharge/outcrop zones of the aquifer storeys are characterized by generally the highest vulnerability. However, these zones, located in the summit to upper midslope of low-mountain ranges, are mostly covered by forest. Generally, the summit position of outcrop zones of the main aquifer storey (moTK-1) lowers the risk of contamination, paradoxically due to the thin soils that prevented lasting agricultural use and settlements. Further zones of higher vulnerability are located in the discharge of sinkhole lineaments or fracture zones that bypass surface water or drains directly into the aquifers. A mapping and structural investigation of these geostructural links will be recommended for proper dimensioning of drinking water protection zones. In comparison to classical karst sites (i.e. massive carbonates) with pronounced karst phenomena (Doerfliger et al., 1999; Witowski et al., 2002), our portrayed setting shows an overall low to moderate vulnerability that is locally elevated by inherent factors (outcrop zones) and inherited features (i.e. karstification of the underlying Middle Muschelkalk subgroup).

\section{Conclusions}

We applied a multi-method approach for a detailed investigation of Critical Zone functioning and reconstruction of groundwater quality in the hitherto scarcely described setting of thin-bedded alternating carbonate-/siliciclastic rocks in a hillslope terrain. For the Hainich Critical Zone Exploratory that offers unique access to a multi-storey groundwater system in the common and widely distributed geological setting, we found the following factor manifestations of local geology, relief, soils and land use for recharge and chemical evolution of groundwater:

- Low-permeable marlstone beds within a marine succession of high lateral continuity represent a number of aquitards that cause a multi-storey hydrostratigraphy of the Upper Muschelkalk formations.

- As a multi-storey hydrostratigraphy exhibits limited vertical percolation, the outcrop zones of dipping aquifer storeys become very important as preferential surface-recharge areas for inputs of matter and energy.

- Diffuse fracture flow dominates over karst/conduit flow in the mixed/multi-layered lithology. Subsurface water flow predominantly takes place in bedding-plane parallel mode/in stratabound fractures of the limestone beds, and it is trackable from the recharge areas along the storeys.

- From summit to footslope positions, travel distances and presumably groundwater ages generally increase. For the individual storeys, however, travel distances to monitoring wells decrease in the downslope direction, whereas their groundwater ages very likely increase due to lower fracturing and higher retention. In the same direction, surface controls (i.e. nutrient input) decrease and subsurface controls (water-rock interaction) increase.

- Compared to more vulnerable settings (i.e. massive carbonate karst, open karst), the mixed carbonatesiliciclastic alternations exhibit moderate intrinsic vulnerability. This is due to lateral continuity of low permeable interbeds, soil covers and caprocks, of which the latter successively increase in thickness towards the footslope. Areas downstream the caprock sinkhole lineaments (and likely transverse valleys) are likely more threatened by anthropogenic (mostly agricultural) inputs.

- The quality of groundwater resources with peripheral hillslope recharge benefits from extensive land management or, ideally (managed/unmanaged) forest coverage, and reveals the importance of recharge area protection.

In general, for mixed carbonate-siliciclastic rock alternations that are prone to developing multi-layered aquifer systems, both the aquifer configuration (spatial arrangement of strata, hillside cutting, outcrop positions) and the related geostructural links (preferential recharge areas, karst phenomena) are major controls of impacting surface and subsurface factors. For the studied type of thin-bedded carbonate aquifer setting, we could demonstrate that a comprehensive investigation of aquifer connectivity in the transit-discharge area as well as soil cover and land use in the recharge area is mandatory and must be rated as indispensable for a thorough understanding of the state and evolution of groundwater quality. Linking groundwater hydrochemistry mostly to surface factors such as land use would result in a contradiction, as groundwater chemistry does not reflect the type of land use in immediate proximity to the wells. Furthermore, footslope wells' hydrochemistry is strongly impacted by aquifer stratigraphy, karst phenomena input and the crossformational ascent of sulfatic groundwater that could not be evaluated without spatial lithostratigraphic data. Geostructural investigation and mapping are essential for the lo- 
calization of aquifer outcrop areas and the assumption of stratigraphy-controlled flow directions. In case the soil group and the type of land use had been neglected, discrimination between influences by natural and anthropogenic controls would have been ambiguous. If the data set included hydrochemistry and multivariate statistics only, the interpretation of this data set would have been ambiguous also, as different chemical surface-subsurface sources result in similar hydrogeochemical compositions.

Recent studies of the CRC AquaDiva focus on signal transit and transformations of surface signals. This is for instance applied to surface-sourced organic matter and microorganisms (Küsel et al., 2016; Schwab et al., 2017; Lazar et al., 2017) to further investigate subsurface connectivity, surfacesubsurface interactions and functions of microbial life in groundwater environments. Further $\mathrm{CZ}$ exploration should also aim at the investigation of deeper strata connection by regional groundwater flow, hydraulic properties and proportions of unsaturated zones and matter processing within.

Data availability. Plot data will be deposited on the BExIS2 (http: //bexis2.uni-jena.de) data portal of the CRC AquaDiva (https:// aquadiva-pub1.inf-bb.uni-jena.de). Access to the AquaDiva data portal for review purposes is granted. Hydrochemical data will not be shared publically at this point of time, as this paper represents the first of a series of three related papers, using similar data sets for different aims. For instance the prepared time series analysis as well as flow and transport models will rely on the same data sets.

Author contributions. BK and RL contributed equally to this article. RL and BK organized and BK conducted the geological mapping, soil mapping, as well as the analysis and correlation of drill cores and geophysical logs. RL organized and partly conducted the groundwater monitoring and obtained authorization from authorities and landowners/companies. PS carried out parts of the soil mapping/description and hydrochemical analyses and carried out the descriptive and multivariate statistics. KUT, SET and KK provided editorial comments on the manuscript. KUT designed and coordinated the project and supervised the field work, data analysis, data presentation and manuscript preparation. KUT, KK and SET are speakers of the CRC AquaDiva.

Competing interests. The authors declare that they have no conflict of interest.

Acknowledgements. The work has been (partly) funded by the Deutsche Forschungsgemeinschaft (DFG) CRC 1076 "AquaDiva" and the state of Thuringia "ProExzellenz" initiative AquaDiv@ Jena (107-1). Field work permits were issued by the responsible state environmental offices of Thuringia, local authorities and landowners. We thank Christine Hess and Maria Fabisch for scientific coordination. Heiko Minkmar supported the field surveys and conducted water and ramcore samplings. Tanja Reiff conducted the Guelph
Permeameter measurements. Sören Drabesch and Marie Mollenkopf constructed the conceptual soil map. Matthias Händel carried out the FT-IR and XRD measurements on bulk rock samples.

Edited by: Alberto Guadagnini

Reviewed by: Erwin Zehe and one anonymous referee

\section{References}

Adams, B. and Foster, S. S. D.: Land-Surface Zoning for Groundwater Protection, Water Environ. J., 6, 312-319, 1992.

AG Boden: Bodenkundliche Kartieranleitung, 5. Edition, Ad-hocArbeitsgruppe Boden der Geologischen Landesämter und der Bundesanstalt für Geowissenschaften und Rohstoffe der Bundesregierung Deutschland, Schweizerbart, Stuttgart, Hannover, 438 pp., 2005.

Agrawal, G. D., Lunkad, S. K., and Malkhed, T.: Diffuse agricultural nitrate pollution of groundwaters in India, Water Sci. Technol., 39, 67-75, 1999.

Aigner, T.: Calcareous tempestites: storm-dominated stratification in Upper Muschelkalk limestones (Middle Triassic, SWGermany), in: Cyclic event stratification, edited by: Einsele, G. and Seilacher, A., Springer, Berlin, Heidelberg, New York, 190198, 1982.

Aigner, T.: Storm depositional systems: Dynamic stratigraphy in modern and ancient shallow-marine sequences, Lect. Notes Earth Sci., 3, Springer, Berlin, Heidelberg, New York, 174 pp., 1985.

Ali, G. A., L'Heureux, C., Roy, A. G., Turmel, M.-C., and Courchesne, F.: Linking spatial patterns of perched groundwater storage and stormflow generation processes in a headwater forested catchment, Hydrol. Process, 25, 3843-3857, https://doi.org/10.1002/hyp.8238, 2011.

Allocca, V., Manna, F., and De Vita, P.: Estimating annual groundwater recharge coefficient for karst aquifers of the southern Apennines (Italy), Hydrol. Earth Syst. Sci., 18, 803-817, https://doi.org/10.5194/hess-18-803-2014, 2014.

Andreu, J. M., Alcalá, F. J., Vallejos, Á., and Pulido-Bosch, A.: Recharge to mountainous carbonated aquifers in SE Spain: Different approaches and new challenges, J. Arid Environ., 75, 1262-1270, https://doi.org/10.1016/j.jaridenv.2011.01.011, 2011.

Bachmair, S., Weiler, M., and Nützmann, G.: Controls of land use and soil structure on water movement: Lessons for pollutant transfer through the unsaturated zone, J. Hydrol., 369, 241-252, https://doi.org/10.1016/j.jhydrol.2009.02.031, 2009.

Backhaus, K., Erichson, B., Plinke, W., and Weiber, R.: Multivariate Analysemethoden: eine anwendungsorientierte Einführung, 14, Springer, Berlin, Heidelberg, 647 pp., 2016.

Bakalowicz, M.: Water geochemistry: water quality and dynamics, Groundw. Ecol., 1, 97-127, 1994.

Blouin, M., Hodson, M. E., Delgado, E. A., Baker, G., Brussaard, L., Butt, K. R., Dai, J., Dendooven, L., Peres, G., Tondoh, J. E., Cluzeau, D., and Brun, J.-J.: A review of earthworm impact on soil function and ecosystem services, Eur. J. Soil. Sci., 64, 161182, https://doi.org/10.1111/ejss.12025, 2013.

Borkhataria, R., Aigner, T., Poeppelreiter, M. C., and Pipping, J. C. P.: Characterization of epeiric "layer-cake" carbonate reservoirs: Upper Muschelkalk (Middle Triassic), the Nether- 
lands, J. Petrol. Geol., 28, 15-42, https://doi.org/10.1111/j.17475457.2005.tb00076.x, 2005.

Brandtner, W.: Böden, in: Erläuterungen zur Geologischen Karte 1:25000 von Thüringen, Blatt 4729 (Schlotheim) und 4730 (Ebeleben) edited by: Grumbt, E., Kästner, H., and Lützner, H., 210-216, Thüringer Landesanstalt für Umwelt und Geologie, Weimar, 1997.

Bullmann, H.: Eigenschaften und Genese periglazialer Deckschichten des Muschelkalks in einem Teilgebiet der Ostthüringer Triaslandschaft, PhD-thesis University of Leipzig, 210 pp., 2010.

Canora, F., Fidelibus, M. D., Sciortino, A., and Spilotro, G.: Variation of infiltration rate through karstic surfaces due to land use changes, Eng. Geol., 99, 210-227, https://doi.org/10.1016/j.enggeo.2007.11.018, 2008.

Cattell, R. B.: The scree test for the number of factors, Multivar. Behav. Res., 1, 245-276, https://doi.org/10.1207/s15327906mbr0102_10, 1966.

Cook, P. G.: A guide to regional groundwater flow in fractured rock aquifers, 151 pp., Australia, CSIRO, 2003.

Deepa, S., Venkateswaran, S., Ayyandurai, R., Kannan, R., and Prabhu, M. V.: Groundwater recharge potential zones mapping in upper Manimuktha Sub basin Vellar river Tamil Nadu India using GIS and remote sensing techniques, Modeling Earth Systems and Environment, 2, 1-13, 2016.

Deumlich, D., Schmidt, R., and Sommer, M.: A multiscale soillandform relationship in the glacial-drift area based on digital terrain analysis and soil attributes, J. Plant. Nutr., 173, 843-851, https://doi.org/10.1002/jpln.200900094, 2010.

Deurer, M., Green, S. R., Clothier, B. E., Böttcher, J., and Duijnisveld, W. H. M.: Drainage networks in soils: A concept to describe bypass-flow pathways, J. Hydrol., 272, 148-162, 2003.

Deutsche Stratigraphische Kommission: Stratigraphische Tabelle von Deutschland (STD 2002), 1. Edition, Stein, Potsdam, 2002.

Dibbern, D., Schmalwasser, A., Lüders, T., and Totsche, K. U.: Selective transport of plant root-associated bacterial populations in agricultural soils upon snowmelt, Soil Biol. Biochem., 69, 187196, 2014

DIN EN ISO 14689-1: Geotechnical investigation and testing Identification and classification of rock - Part 1: Identification and description (ISO 14689-1:2003), 26, 2013.

Doerfliger, N., Jeannin, P. Y., and Zwahlen, F.: Water vulnerability assessment in karst environments: a new method of defining protection areas using a multi-attribute approach and GIS tools (EPIK method), Environ. Geol., 39, 165-176, 1999.

Dreybroth, W.: Processes in karst systems - physics, chemistry and geology, Springer, Heidelberg, New York, 288 pp., 1988.

Dunham, R. J.: Classification of carbonate rocks according to depositional texture, in: Classification of carbonate rocks, edited by: Ham, W. E., AAPG Memoir, 1, 108-121, 1962.

Edmunds, W. M. and Smedley, P. L.: Residence time indicators in groundwater: the East Midlands Triassic sandstone aquifer, Appl. Geochem., 15, 737-752, 2000.

Elrick, D. E. and Reynolds, W. D.: Methods for Analyzing Constant-Head Well Permeameter Data, Soil Sci. Soc. Am. J., 56, 320-323, 1992.

Fier, A.: Entstehung, Eigenschaften und Klassifikation tonreicher Unterbodenhorizonte auf Carbonatgesteinen in norddeutschen
Berg- und Hügelländern, $\mathrm{PhD}$-thesis, University of Halle, 190 pp., 2012.

Ford, D. C. and Williams, P. W.: Karst Hydrogeology and Geomorphology, Wiley, Chichester, 561 pp., 2007.

Furtak, H. and Langguth, H. R.: Zur hydrochemischen Kennzeichnung von Grundwässern und Grundwassertypen mittels Kennzahlen, Mem. IAH-Congress, Hannover, 86-96, 1967.

Garleb, H.: Zu einigen hydrogeochemischen Problemen bei der Erkundung von Grundwasser in der Trias des Thüringer Beckens, Mitteilungsblatt des Thüringischen Geologischen Vereins, $15,41-45,2002$.

Gleeson, T., Novakowski, K., and Kyser, T. K.: Extremely rapid and localized recharge to a fractured rock aquifer, J. Hydrol., 376, 496-509, 2009.

Gleixner, G.: Soil organic matter dynamics: a biological perspective derived from the use of compound-specific isotopes studies, Ecol. Res., 28, 683-695, https://doi.org/10.1007/s11284012-1022-9, 2013.

Goldscheider, N.: Fold structure and underground drainage pattern in the alpine karst system Hochifen-Gottesacker, Eclogae Geol Helv., 98, 1-17, 2005.

Goldscheider, N., Klute, M., Sturm, S., and Hötzl, H.: The PI method - a GIS-based approach to mapping groundwater vulnerability with special consideration of karst aquifers, Z. Angew. Geol., 46, 157-166, 2000.

Goldscheider, N. and Drew, D.: Methods in Karst Hydrogeology, International Contributions to Hydrogeology, 26, Taylor \& Francis, Lodon, Leiden, New York, Philadelphia, Singapore, 264 pp., 2007.

Gradstein, F. M., Ogg, J. G., and Smith, A. G.: A Geologic Time Scale, 1, Cambridge University Press, Cambridge, 2004.

Greitzke, A. and Fiedler, H. J.: Schuttdecken und Bodentypen entlang einer Catena auf Muschelkalk in Buchenbeständen des Hainich (Nordwest-Thüringen), Archiv für Naturschutz und Landschaftforschung, 34, 257-268, 1996.

Grumbt, E., Kästner, H., and Lützner, H.: Erläuterungen zur Geologischen Karte 1:25000 von Thüringen, Blatt 4729 (Schlotheim) und 4730 (Ebeleben), Thüringer Landesanstalt für Umwelt und Geologie, Weimar, 262 pp., 1997.

Guggenberger, G. and Kaiser, K.: Dissolved organic matter in soil: challenging the paradigm of sorptive preservation, Geoderma, 113, 293-310, https://doi.org/10.1016/s0016-7061(02)00366-x, 2003.

Haag, D. and Kaupenjohann, M.: Landscape fate of nitrate fluxes and emissions in Central Europe: A critical review of concepts, data, and models for transport and retention, Agr. Ecosyst. Environ., 86, 1-21, 2001.

Hecht, G.: Grundwässer, in: Geologie von Thüringen, edited by: Seidel, G., Schweizerbart, Stuttgart, 529-586, 2003.

Heinz, J. and Aigner, T.: Hierarchical dynamic stratigraphy in various Quaternary gravel deposits, Rhine glacier area (SW Germany): implications for hydrostratigraphy, Int. J. Earth Sci., 92, 923-938, 2003.

Hem, J. D.: Study and Interpretation of the chemical characteristics of natural water, third edition, U.S. Geological Survey, Water Supply Paper 2254, U.S. Geological Survey, Alexandria, 263 pp., 1985. 
Hiekel, W., Fritzlar, F., Nöllert, A., and Westhus, W.: Die Naturräume Thüringens, Naturschutzreport 21, Thüringer Landesantstalt für Umwelt und Geologie, Jena, 364 pp., 2004.

Hölting, B., Haertlé, T., Hohberger, K. H., Nachtigall, K. H., Villinger, E., Weinzierl, W., and Wrobel, J. P.: Konzept zur Ermittlung der Schutzfunktion der Grundwasserüberdeckung, Geol. Jb., C63, 5-24, Hannover, 1995.

Hoppe, W.: Die hydrogeologischen Grundlagen der Wasserversorgung in Thüringen, Fischer, Jena, 109 pp., 1952.

Hoppe, W.: Die Bedeutung der herzynischen Störungszonen für die Grundwasserführung des Thüringer Beckens, Geologie, 11, 679_ 699, 1962.

Hoppe, W. and Seidel, G.: Geologie von Thüringen, Haack, Gotha, 1000 pp., 1974.

Hsu, C.-H., Han, S.-T., Kao, Y.-H., and Liu, C.-W.: Redox characteristics and zonation of arsenic-affected multi-layers aquifers in the Choushui River alluvial fan, Taiwan, J. Hydrol., 391, 351366, 2010.

IUSS Working Group WRB: World reference base for soil resources (WRB), World soil resources reports, FAO, Rom, 103 pp., 2006.

Jeong, C. H.: Effect of land use and urbanization on hydrochemistry and contamination of groundwater from Taejon area, Korea, J. Hydrol., 253, 194-210, 2001.

Jordan, H. and Weder, H. J.: Hydrogeologie und Methoden, Regionale Hydrogeologie: Mecklenburg-Vorpommern, Brandenburg und Berlin, Sachsen-Anhalt, Sachsen, Thüringen, Enke, Stuttgart, 601 pp., 1995.

Kaiser, E.: Erläuterungen zur geologischen Karte von Preussen und benachbarten Bundesstaaten, Blatt 4828 (Langula), Königlich Preussische Geologische Landesanstalt und Bergakademie, Berlin, 58 pp., 1905.

Khan, M. M. A. and Umar, R.: Significance of silica analysis in groundwater in parts of Central Ganga Plain, Uttar Pradesh, India, Curr. Sci., 98, 1237-1240, 2010.

Klaus, J., Zehe, E., Elsner, M., Külls, C., and McDonnell, J. J.: Macropore flow of old water revisited: experimental insights from a tile-drained hillslope, Hydrol. Earth Syst. Sci., 17, 103118, https://doi.org/10.5194/hess-17-103-2013, 2013.

Kleber, A.: Gliederung und Eigenschaften der Hang-Schuttdecken und ihre Bedeutung für die Bodengenese, Mitteilungen der deutschen bodenkundlichen Gesellschaft, 66, 807-809, 1991.

Kley, J. and Voigt, T.: Late Cretaceous intraplate thrusting in central Europe: Effect of Africa-Iberia-Europe convergence, not Alpine collision, Geology, 36, 839-842, https://doi.org/10.1130/G24930A.1, 2008.

Klimchouk, A. B.: Conceptualisation of speleogenesis in multistorey artesian systems: a model of transverse speleogenesis, Int. J. Speleol., 34, 45-64, https://doi.org/10.5038/1827806X.34.1.4, 2005.

Klimchouk, A. B. and Ford, D. C.: Types of Karst and Evolution of Hydrogeologic Setting, in: Speleogenesis - Evolution of karst aquifers, edited by: Klimchouk, A. B., Ford, D. C., Palmer, A. N. and Dreybrodt, W., and Huntsville, A., National Speleological Society of America, 45-53, 2000.

König, E.: Das Hainichgebiet und seine Karsterscheinungen, Thüringer Höhlen, 4, 92-101, 1930.

Kostic, B. and Aigner, T.: Sedimentary and poroperm anatomy of shoal-water carbonates (Muschelkalk, South-German Basin): an outcrop-analogue study of inter-well spacing scale, Facies, 50, 113-131, https://doi.org/10.1007/s10347-004-0003-z, 2004.

Kottek, M. J., Grieser, C., Beck, B., Rudolf, F., and Rubel, F.: World map of the Koeppen-Geiger climate classification updated, Meteorol. Z., 15, 259-263, https://doi.org/10.1127/09412948/2006/0130, 2006.

Kralik, M., Zieritz, I., Grath, J., Vincze, G., Philippitsch, R., and Pavlik, H.: Hydrochemische Karte Österreichs: Oberflächennaher Grundwasserkörper und Fliessgewässer, Mittelwerte von Wassererhebungsdaten (WGEV-Daten) 1991-2001, Berichte BE-269, 2nd revised edition, Vienna, 14 pp., 2005.

Kunkel, R., Voigt, H.-J., Wendland, F., and Hannappel, S.: Die natürliche, ubiquitär überprägte Grundwasserbeschaffenheit in Deutschland, Schriften des Forschungszentrums Jülich, Reihe Umwelt/Environment, 47, Forschungszentrum Jülich, Jülich, 204 pp., 2004.

Küsel, K., Totsche, K. U., Trumbore, S. E., Lehmann, R., Steinhäuser, C., and Herrmann, M.: How Deep Can Surface Signals Be Traced in the Critical Zone? Merging Biodiversity with Biogeochemistry Research in a Central German Muschelkalk Landscape, Front. Earth Sci., 32, 1-18, https://doi.org/10.3389/feart.2016.00032, 2016.

Lazar, C. S., Stoll, W., Lehmann, R., Herrmann, M., Schwab, V. F., Akob, D. M., Nawaz, A., Wubet, T., Buscot, F., Totsche, K. U., and Küsel, K.: Archaeal Diversity and $\mathrm{CO}_{2}$ Fixers in Carbonate/Siliciclastic-Rock Groundwater Ecosystems, Archaea, 2017, 2136287, https://doi.org/10.1155/2017/2136287, 2017.

Lucia, F. J.: Petrophysical parameters estimated from visual descriptions of carbonate rocks: A field classification of carbonate pore space, J. Petrol. Technol., 216, 221-224, https://doi.org/10.2118/10073-PA, 1983.

Malcher, G.: Karstland Thüringen - Morphologie Hydrologie in Thüringen, in: Thüringen - Karst und Höhle 2011-2014, edited by: Verband der Deutschen Höhlen und Karstforscher, München, 9-24, 2014.

Matthess, G.: Lehrbuch der Hydrogeologie, Band 2, Die Beschaffenheit des Grundwassers, Bornträger, Berlin, Stuttgart, 483 pp., 1994.

Meier, S., Bauer, J. F., and Philipp, S. L.: Fault zone characteristics, fracture systems and permeability implications of Middle Triassic Muschelkalk in Southwest Germany, J. Struct. Geol., 70, 170-189, 2015.

Mempel, G.: Die hydrogeologischen Verhältnisse von NordwestThüringen, Jahrbuch der Preußischen Geologischen Landesanstalt, 59, Preußische Geologische Landesanstalt, Berlin, 587-646, 1939.

Merz, G.: Zur Petrographie, Stratigraphie, Paläogeographie und Hydrogeologie des Muschelkalks (Trias) im Thüringer Becken, Zeitschrift der geologischen Wissenschaften, 15, 457-473, 1987.

Moore, P. J., Martin, J. B., and Screaton, E. J.: Geochemical and statistical evidence of recharge, mixing, and controls on spring discharge in an eogenetic karst aquifer, J. Hydrol., 376, 443-455, https://doi.org/10.1016/j.jhydrol.2009.07.052, 2009.

Münch, J. M., Totsche, K. U., and Kaiser, K.: Physicochemical factors controlling the release of dissolved organic dissolved organic carbon release in forest subsoils - a column study, Eur. J. Soil Sci., 53, 311-320, https://doi.org/10.1046/j.13652389.2002.00439.x, 2002. 
Muir, K. S. and Johnson, M. J.: Classification of ground-water recharge potential in three parts of Santa Cruz County, California, U.S. Geological Survey, Open-File Report 79-1065, 1979.

Nennstiel, K.: Springquellen und andere starke Quellen Thüringens, Beiträge zur Geologie von Thüringen, 3, 33-66, 1933.

Ockert, W. and Rein, S.: Biostratigraphische Gliederung des Oberen Muschelkalkes von Thüringen, Beiträge zur Geologie von Thüringen, 7, 195-228, 2000.

Odling, N. E., Gillespie, P., Bourgine, B., Castaing, C., Chiles, J. P., Christensen, N. P., Fillion, E., Genter, A., Olsen, C., Thrane, L., Trice, R., Aarseth, E., Walsh, J. J., and Watterson, J.: Variations in fracture system geometry and their implications for fluid flow in fractured hydrocarbon reservoirs, Petrol. Geosci., 5, 373-384, 1999.

Otto, C.: Historische Landschaftsanalyse im Nationalpark Hainich und deren Moeglichkeiten der Anwendung, diploma thesis, Fachhochschule Eberswalde, 87 pp., 2000.

Palmer, A. N.: Geochemical models for the origin of macroscopic solution porosity in carbonate rocks, in: Unconformities and porosity in carbonate strata, edited by: Budd A. D., Saller A. H., and Harris, P. M., AAPG Memoir, 63, Tulsa (Oklahoma), 77101, 1995.

Patzelt, G.: Der Hainich, Cordier, Heiligenstadt, 48 pp., 1998.

Piper, A. M.: A graphic procedure in the geochemical interpretation of water analysis, Eos T. Am. Geophys. Un., 25, 914-928, https://doi.org/10.1029/TR025i006p00914, 1944.

Poser, S.: Rekonstruktion der Nutzungsgeschichte für einen Teilbereich des NLP Hainich mit Anlage vegetationskundlicher Dauerbeobachtungsflächen und Vorschlägen zur Besucherinformation, Diploma thesis, Fachhochschule Anhalt, 108 pp., 2004.

Pronk, M., Goldscheider, N., Zopfi, J., and Zwahlen, F.: Percolation and Particle Transport in the Unsaturated Zone of a Karst Aquifer, Ground Water, 47, 361-369, https://doi.org/10.1111/j.1745-6584.2008.00509.x, 2009.

Rau, D. and Unger, K. P.: Erläuterungen zur Bodenkarte von Thüringen, Blatt 4732 (Kindelbrück), Thüringer Landesanstalt für Geologie und Umwelt, Weimar, 108 pp., 1997.

Röhling, S. and Safar, D.: Forstgeschichte und waldbauliche Nutzung des Weberstedter Holzes ab dem 18. Jahrhundert im heutigen Nationalpark Hainich, Belegarbeit Lehrgebiet Forstgeschichte, University of Dresden, 24 pp., 2004.

Schrumpf, M., Kaiser, K., Guggenberger, G., Persson, T., KögelKnabner, I., and Schulze, E.-D.: Storage and stability of organic carbon in soils as related to depth, occlusion within aggregates, and attachment to minerals, Biogeosciences, 10, 16751691, https://doi.org/10.5194/bg-10-1675-2013, 2013.

Schwab, V. F., Herrmann, M., Roth, V.-N., Gleixner, G., Lehmann, R., Pohnert, G., Trumbore, S., Küsel, K., and Totsche, K. U.: Functional diversity of microbial communities in pristine aquifers inferred by PLFA- and sequencing-based approaches, Biogeosciences, 14, 2697-2714, https://doi.org/10.5194/bg-142697-2017, 2017.

Seidel, G.: Geologie von Thüringen, Schweizerbart, Stuttgart, 601 pp., 2003

Shaban, A., Khawlie, M., and Abdallah, C.: Use of remote sensing and GIS to determine recharge potential zones: the case of Occidental Lebanon, J. Hydrol., 14, 433-443, 2006.
Sharp Jr., J. M.: A Glossary of Hydrogeological Terms, Department of Geological Sciences, The University of Texas: Austin (Texas), 63 pp., 2007.

Simon, T.: The Muschelkalk karst in southwest Germany, in: Tracer hydrology 97 - proceedings of the international symposium on water tracing, edited by: Kranjc, A., Portoroz (Slovenia), 26-31 May 1997, 297-286, 1997.

Smart, P. L. and Hobbs, S. L.: Characterization of carbonate aquifers - A conceptual base, in: Environmental problems in karst terranes and their solutions: Bowling Green, KY, 1-14, 1986.

Steward, D. R., Yang, X., Lauwo, S. Y., Staggenborg, S. A., Macpherson, G. L., and Welch, S. M.: From precipitation to groundwater baseflow in a native prairie ecosystem: a regional study of the Konza LTER in the Flint Hills of Kansas, USA, Hydrol. Earth Syst. Sci., 15, 3181-3194, https://doi.org/10.5194/hess-15-3181-2011, 2011.

Suk, H. and Lee, K. K.: Characterization of a Ground Water Hydrochemical System Through Multivariate Analysis: Clustering Into Ground Water Zones, Ground Water, 37, 348-366, https://doi.org/10.1111/j.1745-6584.1999.tb01112.x, 1999.

Suschka, A.: Erdfälle im Nationalpark Hainich (Thüringen): Natürliche und anthropogen bedingte Veränderungen von Erdfallstandorten in die Umweltbildung, diploma thesis, University of Greifswald, 96 pp., 2007.

TLUG (Thüringer Landesanstalt für Umwelt: Grundwasser in Thüringen): Bericht zu Menge und Beschaffenheit, Thüringer Landesanstalt für Umwelt und Thüringer Landesanstalt für Geologie, Erfurt, 163 pp., 1996.

TLUG (Thüringer Landesanstalt für Umwelt und Geologie): Umwelt regional, available at: http://www.tlug--jena.de/uw_ raum/umweltregional/uh/uh09.html, last access: 18 January 2016.

Totsche, K. U., Jann, S., and Kögel-Knabner, I.: Release of polycyclic aromatic hydrocarbons, dissolved organic carbon, and suspended matter from disturbed NAPLcontaminated gravelly soil material, Vadose Zone J., 5, 469-479, https://doi.org/10.2136/vzj2005.0057, 2006.

Totsche, K. U., Jann, S., and Kögel-Knabner, I.: Single event driven release of $\mathrm{PAH}$, colloids and suspended matter under natural conditions, Vadose Zone J., 6, 233-243, https://doi.org/10.2136/vzj2006.0083, 2007.

Totsche, K. U., Amelung, W., Gerzabek, M. H., Guggenberger, G., Klumpp, E., Knief, C., Lehndorff, E., Mikutta, R., Peth, S., Prechtel, A., Ray, N., and Kögel-Knabner, I.: Microaggregates in soils, J. Plant. Nutr. Soil. Sc., 1-33, https://doi.org/10.1002/jpln.201600451, 2017.

Urich, P. B.: Land use in karst terrain: review of impacts of primary activities on temperate karst ecosystems, Department of Conservation, Wellington, 58 pp., 2002.

Vías, J. M., Andreo, B., Perles, M. J., Carrasco, F., Vadillo, I., and Jiménez, P.: Proposed method for groundwater vulnerability mapping in carbonate (karstic) aquifers: the COP method, Hydrogeol. J., 14, 912-925, 2006.

Voigt, T., von Eynatten, H., and Franzke, H. J.: Late Cretaceous unconformities in the Subhercynian Cretaceous Basin (Germany), Acta Geol. Pol., 54, 673-694, 2004.

Völker, C. and Völker, R.: Bemerkenswertes zu Karstquellen im Bereich Mühlhausen und des Eichsfeldes, in: Die Geologie 
von NW Thüringen, edited by: Thüringer Geologischer Verein (TGV), Exkursionsführer, 10-17, 2002.

Vrba, J. and Zaporozec, A.: Guidebook on mapping groundwater vulnerability, International Association of Hydrogeologists, International Contributions to Hydrogeology, 16, 131 pp., Heise, Hannover, 1994.

Ward, J. H.: Hierarchical Grouping to Optimize an Objective Function, J. Am. Statist. Assoc., 48, 236-244, 1963.

Wätzel, A.: Geologische Heimatkunde des Unstrut-HainichKreises, Mühlhäuser Beiträge, 30, 20-41, 2007.

Weigand, H. and Totsche, K. U.: Flow and reactivity effects on dissolved organic matter transport in soil columns, Soil Sci. Soc. Am. J., 62, 1268-1274, https://doi.org/10.2136/sssaj1998.03615995006200050017x, 1998.

Weiler, M. and Naef, F.: An experimental tracer study of the role of macropores in infiltration in grassland soils, Hydrol. Process., 17, 477-493, https://doi.org/10.1002/hyp.1136, 2003.

Weiss, A. D.: Topographic Position and Landforms Analysis, Conference Poster, ESRI International User Conference, San Diego, CA, USA, 2001.
White, W. B.: Conceptual Models for Carbonate Aquifers (reprint 2012), Ground Water, 7, 180-186, 1969.

Wienhöfer, J. and Zehe, E.: Predicting subsurface stormflow response of a forested hillslope - the role of connected flow paths, Hydrol. Earth Syst. Sci., 18, 121-138, https://doi.org/10.5194/hess-18-121-2014, 2014.

Witkowski, A. J., Rubin, K., Kowalczyk, A., Różkowski, A., and Wrobel, J.: Groundwater vulnerability map of the Chrzanów karst-fissured Triassic aquifer (Poland), Env. Geol., 44, 59-67, https://doi.org/10.1007/s00254-002-0735-4, 2003.

Wong, C. I., Mahler, B. J., Musgrove, M., and Banner, J. L.: Changes in sources and storage in a karst aquifer during a transition from drought to wet conditions, J. Hydrol., 468, 159-172, 2012.

Worthington, S. R. H.: A Comprehensive strategy for understanding flow in carbonate aquifer, in: Karst Modeling, Proceedings of the symposium held 24-27 February, 1999 Charlottesville (Virginia), edited by: Palmer, A. N., Palmer, M. V., and Sasowsky, I. D., Karst Waters Institute Special Publication 5, Karst Waters Institute, Charles Town (West Virginia), 30-37, 1999. 